Article

\title{
Explaining Intricate Morphometric Variability with Environmental Predictors: The Case of Globularia cordifolia Species Complex
}

\author{
Michele Innangi 1,*®D, Maja Friščić ${ }^{2}$, Kroata Hazler Pilepić ${ }^{2, \dagger}{ }^{\text {, Tiziana Danise }}{ }^{1}$, Fabio Conti ${ }^{3}$, \\ Fabrizio Bartolucci ${ }^{3}$ (D) Antonietta Fioretto ${ }^{1}$ (D) and Lorenzo Peruzzi ${ }^{4}$ (D) \\ 1 Department of Environmental, Biological, Pharmaceutical Sciences and Technologies, University of \\ Campania “Luigi Vanvitelli”, Via Vivaldi 43, 81100 Caserta, Italy; tiziana.danise@unicampania.it (T.D.); \\ antonietta.fioretto@unicampania.it (A.F.) \\ 2 Department of Pharmaceutical Botany, Faculty of Pharmacy and Biochemistry, University of Zagreb, \\ Schrottova 39, 10000 Zagreb, Croatia; mfriscic@pharma.hr (M.F.); khazler@pharma.hr (K.H.P.) \\ 3 Floristic Research Center of the Apennines, University of Camerino-Gran Sasso-Laga National Park, San \\ Colombo, 67021 Barisciano (L'Aquiila), Italy; fabio.conti@unicam.it (F.C.); fabrizio.bartolucci@unicam.it (F.B.) \\ 4 Department of Biology-Botany Unit, University of Pisa, Via Derna 11, 56126 Pisa, Italy; \\ lorenzo.peruzzi@unipi.it \\ * Correspondence: michele.innangi@unicampania.it \\ + Hazler Pilepić passed away during the initial stages of this research.
}

Received: 16 January 2020; Accepted: 28 February 2020; Published: 3 March 2020

check for updates

\begin{abstract}
Globularia is a genus of small evergreen and perennial shrubs that are widespread in Europe. Globularia section Empetron includes a group of three species, G. cordifolia, G. meridionalis, and G. neapolitana, that have been taxonomically disputed for more than 150 years. Many morphological features have been proposed to discriminate these species. Nevertheless, evidence from both past and recent literature suggest that these differences among species are not consistent. In order to shed new light in this long-disputed group, we investigated 10 populations of the G. cordifolia species complex with both classical and geometric morphometrics and used environmental predictors in multivariate regression to explain patterns of variation. Our results showed that bract area and calyx teeth length are correlated with solar radiation and annual precipitation, whereas leaf dry mass per unit area can be explained by temperature seasonality. Leaf shape can be explained by temperature seasonality as well, although with a lower amount of explanatory and predictive power. Despite a comparatively low sample size in terms of populations, our results were based on a large number of individuals and were supported by a robust statistical approach. We can conclude that differences among the three species of Globularia could be related to the combined effects of several ecological variables and might not have taxonomical value. Our novel approach provided an ecological interpretation on a species complex that makes up a continuum of forms within the environmental framework of the Mediterranean basin.
\end{abstract}

Keywords: Globularia section Empetron; Globularia cordifolia; classical morphometrics; geometric morphometrics; morphological variation; ecological statistics; geographical predictors; bioclimatic predictors

\section{Introduction}

Globularia L. is a genus of angiosperms composed mostly of small evergreen and perennial shrubs, recognizable by spherical inflorescences of blue-violet flowers [1-4]. The number of species belonging to this genus and their taxonomic status have been interpreted in several ways by the authors who have studied these plants over the years. Currently, 27 taxa are included in this genus [5], of which many 
are narrow endemics [1,6,7]. Recent molecular studies have demonstrated that Globularia, which was traditionally included in a separate family (Globulariaceae) along with Poskea Vatke, actually belongs to Plantaginaceae [8]. Otto Schwarz proposed the first extensive classification of Globularia, recognizing 22-25 taxa [3,9]. Subsequently, after years of discordant or incomplete taxonomy, the genus underwent taxonomic modifications by several authors $[4,6,10]$. In the current classification of the genus Globularia, eight sections are recognized: G. section Lytanthus (Wettst.) O.Schwarz, G. section Polycephalium O.Schwarz, G. section Carradoria (A.DC.) Wettst., G. section Hellenion O.Schwarz, G. section Globularia (Syn.: section Aphyllanthes O.Schwarz), G. section Alypum (Fisch.) O.Schwarz, G. section Empetron O.Schwarz, and G. section Gymnocladium O.Schwarz [4]. Molecular data have provided evidence for Miocene origin of Globularia, and the independent evolution during the Pleistocene in three European Alpine and two Mediterranean groups [11-14]. Accordingly, representatives of the genus are widespread in most of Europe. However, the highest concentration of taxa is found in Central and Southern Europe, Anatolia, Northern Africa, and Macaronesia [1,5]. Disjunct populations are also found in the Atlantic and Swedish islands and around the Volga [5]. Most species are adapted to dry and open habitats, often on calcareous soils, in meadows or on bare rocks [6].

The typical life-forms of Globularia include hemicryptophytes and chamaephytes, with a primary root dominating the root system in most species during the whole life of the plant, with the exception of the G. cordifolia species complex (Figures 1 and 8) [4]. Stems are made of branches and stolons, along with flowering scapes, which often possess one to many bracts [4]. When in small number, such bracts on the flowering scape are known as scales [2]. True leaves, which are simple and mostly evergreen, can be arranged in several ways, but are generally sparse or fused in a basal rosette or on several bundles [4]. Flowers are collected in solitary capitula, with individual flowers clustered on a common receptacle. Such receptacles can be hairy, conical, cylindrical, or globose. The external flower bracts forming the envelope are more or less similar in shape to the internal ones, and both type of bracts often persist on the receptacle after flowering. Fruits are achenes enclosed in a persistent calyx, usually $1-1.5 \times 0.5 \mathrm{~mm}[6,15]$.

Some Globularia species are well known for their medicinal use [16,17]. Accordingly, several species of Globularia have been phytochemically investigated, given their contents in iridoids and phenolic compounds with potential biological applications [18]. Conversely, in the last decades, the genus has been scarcely studied from a taxonomical point of view, with some exceptions [1,7,19-21]. During the years, some species have always been clearly recognizable from a taxonomic point of view (e.g., Globularia alypum L., Globularia nudicaulis L., or Globularia incanescens Viv.), whereas there has always been great confusion on G. cordifolia L. and allied species [6,21-24]. Globularia section Empetron includes G. cordifolia, Globularia meridionalis (Podp.) O.Schwarz, Globularia repens Lam., and the narrow endemic Globularia neapolitana O.Schwarz, which can all be found in Italy [2,4,25]. All of these species share most of their morphological character-states, being woody shrubs no taller than $25 \mathrm{~cm}$, living in the same habitats, that is, calcareous rocks from sea level to high elevations (Figure 1) [2,6]. 


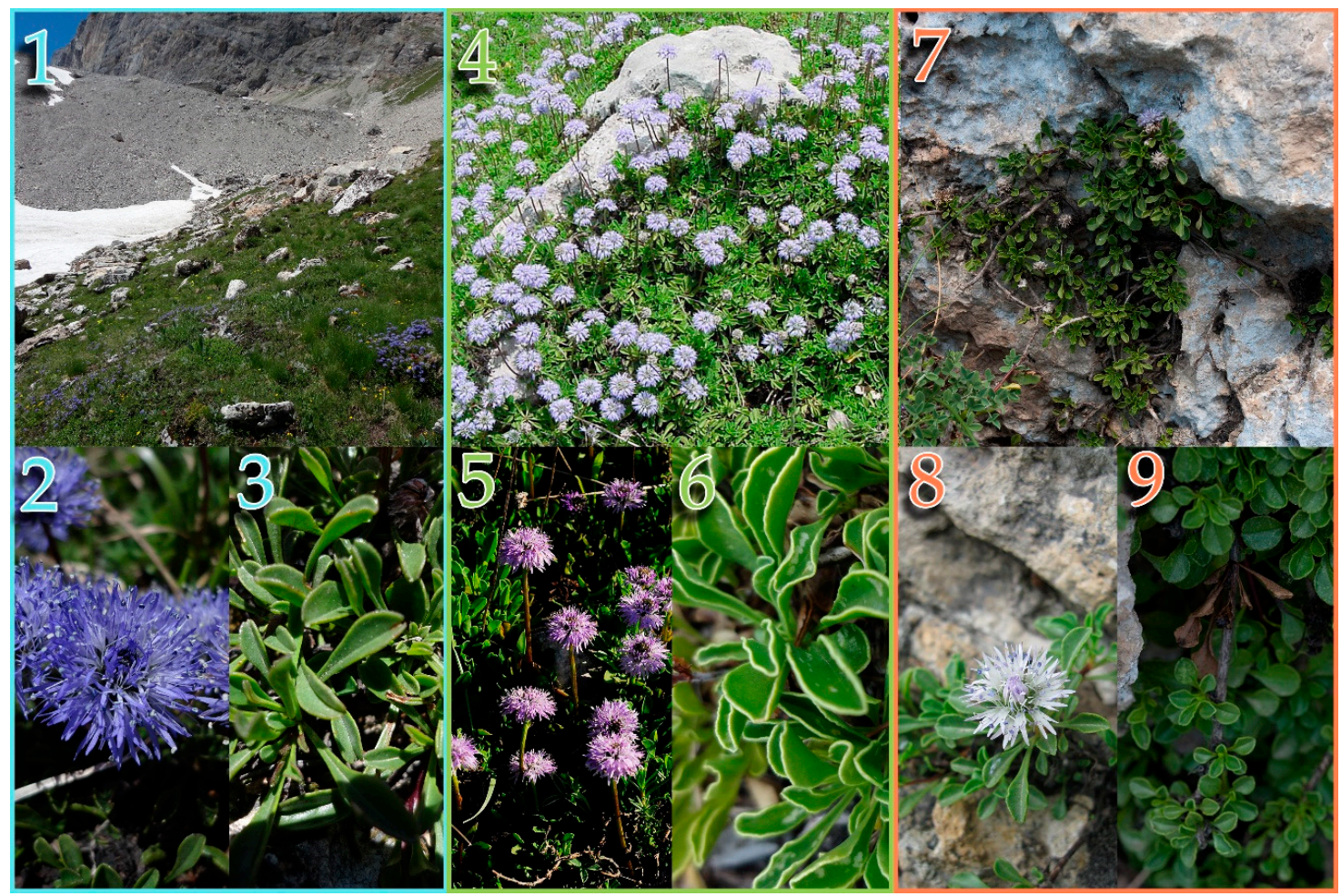

Figure 1. Globularia cordifolia species complex. Pictures 1-3 show habitat, flowers, and leaves of G. cordifolia from Val de Rhêmes, Vallée d'Aoste, Italy. Pictures 4-6 show G. meridionalis habitat and leaves from Timpa del Principe-Frascineto, Calabria, Italy, whereas picture 5 shows flowers from Fonte Vedice, Abruzzo, Italy. Pictures 7-9 show habitat, flowers, and leaves of G. neapolitana from Monte S. Angelo a Tre Pizzi, Campania, Italy. (Photos 1-4 and 6-L.P., 5-F.C., 7 and 9-M.I., and photo 8 was kindly granted by A. Izzo).

Globularia cordifolia shows the largest area of occurrence, from Turkey to Spain, whereas G. repens is limited to the western Mediterranean, from Spain to northern Italy [6]. Globularia meridionalis is restricted to the Balkans, from Greece and Bulgaria to Croatia, Slovenia, and Austria, and extends along the Italian Apennines [3]. In the southern Apennines, the narrow endemic G. neapolitana is known for some populations in the Sorrento-Amalfi peninsula and the Island of Capri [26-28], although some populations have been reported in the nearby Taburno-Camposauro complex in sympatry with G. meridionalis $[29,30]$. According to early karyological data, G. meridionalis is diploid with $2 n=16$ chromosomes, although autopolyploids exist with $2 n=32$ chromosomes, whereas $G$. cordifolia $(2 n=32)$ is an allotetraploid allegedly originating from G. repens $(2 n=16)$ and G. meridionalis [9,31]. However, according to Milletti [6], there is no evidence of true karyological differences between G. cordifolia and G. meridionalis, given that tetraploid level $2 n=32$ is reported for both species, as confirmed also by other authors [22]. On the other hand, G. repens is diploid with $2 n=16$ chromosomes [10], and G. neapolitana has been reported as tetraploid $(2 n=32)$ or even $2 n=16$ in some cases [23]. Thus, with the exception of G. repens, all species in G. section Empetron are, or can be, tetraploid; share the same habitats; and largely overlap in their distribution.

Concerning the morphological features that have been used to distinguish these species, Milletti [6] made an extensive survey of the different criteria used throughout the years, which can be summarized as (a) the general habitus of the plant, including its life-form and overall size; (b) the leaf size and its apex shape; (c) the scale number on the flowering scape; (d) the shape of the outer and inner bracts, including the presence and abundance of hairs; and (e) the calyx shape, with particular regard to the ratio between the teeth and the tube length. Pignatti [2] used a combination of the aforementioned features to circumscribe the species complex within G. section Empetron, but according to Milletti [6] 
there is too much variability in most of these features, with the exception of the calyx. According to Ravnik [21,22], populations from G. cordifolia species complex can be different from one another in the size and shape of their leaf blades, the serration of the leaf edge, the type of the flower calyx and corolla, and the shape and sharpness of the outer bracts. However, they never differ in all of these features, whereas different types of the same feature can, at the same time, be present in an individual plant. The same author suggested these differences to be consequences of polymorphisms and proposed to consider the sole taxon G. cordifolia [21,22].

Evidence from recent molecular data support the hypothesis that G. section Empetron is one of the latest branching lineages in the evolution of Globularia, and that G. meridionalis, G. cordifolia, and G. neapolitana are close to G. repens [1,5]. According to Milletti [6], such large variability could be explained by the wide area of occurrence of the species and their habitat fragmentation, noting a large polymorphism and quoting Willkomm [32] for the explanation, "Hic speciei typus per innumeras formas intermedias transit in varietatem" (English: "This type of species passes from variety to variety through countless intermediate forms"). Admittedly, mechanisms of speciation are still poorly understood in Globularia, and fine-scale distributional, population genetic, morphological, and reproductive data are needed to further clarify the evolutionary history of these plants [5].

Yet, there is a large amount of recent literature exploring morphological variations in plants as dependent on environmental factors. For instance, sea daffodils (Pancratium maritimum L.) vary their morphological features according to the bioclimatic variables to which they are exposed, including precipitation, average annual temperatures, and strong irradiance [33]. Subtler climate effects were observed in Pinus flexilis E.James, where there was no macroscopic variation in morphology on a large elevation gradient (1600-3300 m), yet stomatal density was inversely correlated with elevation [34]. Climate has been shown to have strong potential effects on flower morphology as well [35]. Undoubtedly, the availability of global-scale bioclimatic variables [36] and the introduction of novel statistical techniques can help to shed new light to ecological and biological phenomena [37]. Yet, the study of morphology remains a key-instrument in plant systematics and ecology, both with traditional approaches [38-40] or with modern geometric morphometrics [41-43].

Thus, in our research, we tested the hypothesis that the variability in shape and size observed in G. cordifolia species complex could be explained by the impact of bioclimatic variables. In order to do so, we used both classical and geometric morphometrics, by extracting principal components (PCs) from multivariate datasets and by using them as outcomes, as well as bioclimatic variables as predictors, in order to test the effect of climate on size and shape variability. Although our final outputs were based on a comparatively small sample size (10 populations; Figure 2 and Table 3), the data were derived from a large number of individuals and organs per populations, and were based on robust, cross-validated statistical models. 


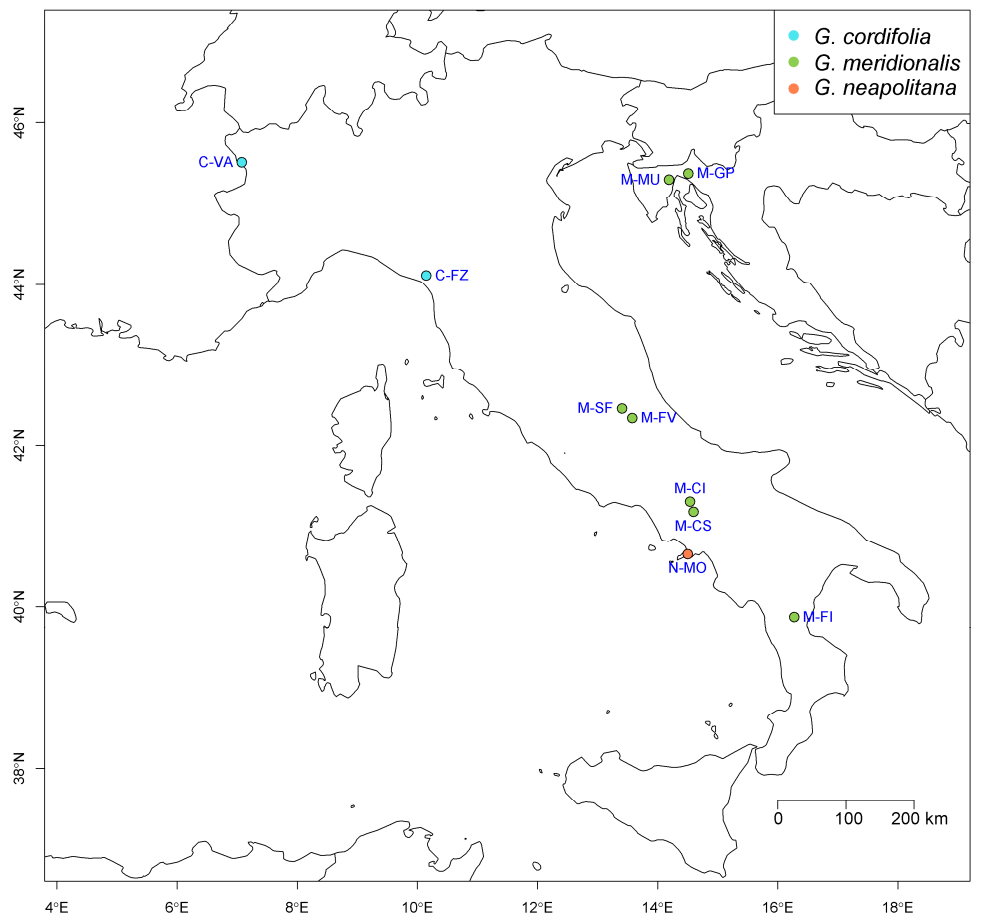

Figure 2. Distribution of the sampled populations of G. cordifolia, G. meridionalis, and G. neapolitana. For details about the single populations, refer to Table 3.

\section{Results}

\subsection{Classical Morphometrics}

Results from classical morphometric analysis for all weakly correlated variables used in the Principal component analysis (PCA) can be seen in Table 1, whereas all other variables are available in Supplement 1 and Supplement 2. Leaf per mass area (LMA) was not strongly different among populations, with a mean value of $199.68 \pm 3.79 \mathrm{~g} / \mathrm{m}^{2}$. Maximum values were reached in G. meridionalis (M-GP) and minimum in G. neapolitana (N-MO). No remarkable difference emerged among the studied species, with the two populations of G. cordifolia comparable to the seven G. meridionalis, as well as to the single population of G. neapolitana. Data concerning the calyx showed moderate amount of variability. As for tube length, highest values $(\geq 1.8 \mathrm{~mm})$ were reached in several populations (C-FZ, M-CS, N-MO, and M-FI) that belong to all studied species, whereas low values were found in M-MU $(1.47 \pm 0.07 \mathrm{~mm})$. Additionally, on one hand, the length of the calyx teeth varied from $2.33 \pm 0.11 \mathrm{~mm}$ in C-VA (G. cordifolia) to $1.82 \pm 0.06$ in M-CS (G. meridionalis). On the other hand, there was no pattern among species, with populations as distant as almost $1000 \mathrm{~km}$ (C-VA vs. M-FI, see Figure 2) showing no significant difference. Thus, the ratio between the lengths of the calyx teeth and tube also showed little variability, with a range of 1.0-1.5. Once again, there was no noticeable pattern among populations and within species, with a few populations showing calyx teeth clearly longer than the tube (C-VA, M-MU, M-FV, Supplement 1). Data for the outer bracts showed an even smaller degree of variability. Accordingly, all populations shared similar values of outer bract area, with a mean value of $3.95 \pm 0.14 \mathrm{~mm}^{2}$. Similarly, inner bract length showed little variability, with significant differences only between M-GP and M-FI, with a similar pattern for inner bract area, which was on average $2.84 \pm 0.08 \mathrm{~mm}^{2}$. Significant differences for inner bract area were found only between N-MO and M-FV, whereas all other values were intermediate. Noticeably, when considering variability at a species level rather than at population level, the only variable that showed significant differences was LMA, which was higher in G. meridionalis $\left(208.74 \pm 4.51 \mathrm{~g} \mathrm{~m}^{-2}\right)$ compared to both G. cordifolia and G. neapolitana (Table 1). 
Table 1. Data for the classical morphometric variables used in the principal component analysis (PCA). Values are reported as mean \pm standard error of the mean per population and per species, whereas the number in brackets is the sample size (i.e., number of individuals per population or species). Values that do not share a letter are significantly different $(p<0.05)$.

\begin{tabular}{|c|c|c|c|c|c|c|c|}
\hline \multicolumn{2}{|c|}{ Population } & \multirow{2}{*}{$\begin{array}{c}\text { Leaves } \\
\text { LMA }\left(\mathrm{g} / \mathrm{m}^{2}\right)\end{array}$} & \multicolumn{2}{|c|}{ Calyces } & \multirow{2}{*}{$\begin{array}{l}\text { Outer Bracts } \\
\text { Area }\left(\mathrm{mm}^{2}\right)\end{array}$} & \multicolumn{2}{|c|}{ Inner Bracts } \\
\hline ID & Species & & $\begin{array}{l}\text { Tube Length } \\
\text { (mm) }\end{array}$ & $\begin{array}{l}\text { Teeth Length } \\
\text { (mm) }\end{array}$ & & Length (mm) & Area $\left(\mathrm{mm}^{2}\right)$ \\
\hline C-VA & G. cordifolia & $182.24 \pm 11.25(9) \mathrm{bc}$ & $1.56 \pm 0.04(9) b c$ & $2.33 \pm 0.11(9) \mathrm{a}$ & $2.73 \pm 0.53(5) \mathrm{a}$ & $3.62 \pm 0.18(7) a b$ & $2.49 \pm 0.32(7) a b$ \\
\hline C-FZ & G. cordifolia & $187.82 \pm 12.93(11) b c$ & $1.85 \pm 0.04(11) \mathrm{a}$ & $1.92 \pm 0.07(11) b c$ & $4.67 \pm 0.50(5) \mathrm{a}$ & $4.08 \pm 0.17(9) \mathrm{ab}$ & $2.95 \pm 0.17(9) \mathrm{ab}$ \\
\hline M-GP & G. meridionalis & $257.86 \pm 9.70(15) \mathrm{a}$ & $1.74 \pm 0.04(15) \mathrm{ab}$ & $2.00 \pm 0.03(15) a b c$ & $4.44 \pm 0.14(7) \mathrm{a}$ & $4.2 \pm 0.09$ (15) a & $2.92 \pm 0.14(15) \mathrm{ab}$ \\
\hline M-MU & G. meridionalis & $216.41 \pm 9.59(11) \mathrm{ab}$ & $1.47 \pm 0.07(6) c$ & $1.97 \pm 0.11(6) a b c$ & $4.09 \pm 0.24(6) \mathrm{a}$ & $4.13 \pm 0.18(5) \mathrm{ab}$ & $2.80 \pm 0.13(5) \mathrm{ab}$ \\
\hline M-SF & G. meridionalis & $217.07 \pm 6.95(9) \mathrm{ab}$ & $1.68 \pm 0.08(6) \mathrm{abc}$ & $1.85 \pm 0.04(6) b c$ & $3.69 \pm 0.77(4) \mathrm{a}$ & $3.73 \pm 0.17(7) a b$ & $2.88 \pm 0.22(7) \mathrm{ab}$ \\
\hline M-FV & G. meridionalis & $214.26 \pm 11.76(9) \mathrm{ab}$ & $1.57 \pm 0.04(9) b c$ & $2.00 \pm 0.07(9) \mathrm{abc}$ & $2.97 \pm 0.28(3) \mathrm{a}$ & $4.13 \pm 0.18(8) a b$ & $2.18 \pm 0.16(8) b$ \\
\hline $\mathrm{M}-\mathrm{CI}$ & G. meridionalis & $188.65 \pm 8.67(11) b c$ & $1.74 \pm 0.06(11) \mathrm{ab}$ & $2.06 \pm 0.08(11) \mathrm{abc}$ & $3.61 \pm 0.25(5) \mathrm{a}$ & $4.14 \pm 0.15(10) a b$ & $3.07 \pm 0.21(10) \mathrm{ab}$ \\
\hline M-CS & G. meridionalis & $184.09 \pm 8.29(15) b c$ & $1.85 \pm 0.06(15) \mathrm{a}$ & $1.82 \pm 0.06(15) \mathrm{c}$ & $4.46 \pm 0.31(7) \mathrm{a}$ & $4.09 \pm 0.18(13) \mathrm{ab}$ & $2.99 \pm 0.22(13) a b$ \\
\hline M-FI & G. meridionalis & $176.49 \pm 5.64(11) b c$ & $1.98 \pm 0.12(11) \mathrm{a}$ & $2.02 \pm 0.1(11) a b c$ & $4.38 \pm 0.55(6) \mathrm{a}$ & $3.45 \pm 0.23(10) b$ & $2.45 \pm 0.32(10) a b$ \\
\hline $\mathrm{N}-\mathrm{MO}$ & G. neapolitana & $169.90 \pm 5.88(15) \mathrm{c}$ & $1.81 \pm 0.04(15) \mathrm{a}$ & $2.14 \pm 0.06(15) \mathrm{ab}$ & $3.72 \pm 0.32(9) \mathrm{a}$ & $4.03 \pm 0.26(9) \mathrm{ab}$ & $3.41 \pm 0.31(9) \mathrm{a}$ \\
\hline All & G. cordifolia & $185.32 \pm 8.53(20) b$ & $1.72 \pm 0.04(20) \mathrm{a}$ & $2.10 \pm 0.07(20) \mathrm{a}$ & $3.70 \pm 0.47(10) \mathrm{a}$ & $3.88 \pm 0.13(16) \mathrm{a}$ & $2.75 \pm 0.17(16) \mathrm{a}$ \\
\hline All & G. meridionalis & $208.74 \pm 4.51(81) \mathrm{a}$ & $1.75 \pm 0.03(73) \mathrm{a}$ & $1.96 \pm 0.03(73) \mathrm{a}$ & $4.07 \pm 0.15(38) \mathrm{a}$ & $4.00 \pm 0.07(68) \mathrm{a}$ & $2.79 \pm 0.08(68) \mathrm{a}$ \\
\hline All & G. neapolitana & $169.90 \pm 5.88(15) b$ & $1.81 \pm 0.04(15) \mathrm{a}$ & $2.14 \pm 0.06(15) \mathrm{a}$ & $3.72 \pm 0.32(9) \mathrm{a}$ & $4.03 \pm 0.26(9) \mathrm{a}$ & $3.41 \pm 0.31(9) \mathrm{a}$ \\
\hline
\end{tabular}


Principal component analysis (PCA) for classical morphometric data showed that $69 \%$ of total variance could be explained by the first two PCs (Figure 3). Accordingly, 39\% of total variance was explained by PC1, highlighting that outer and inner bracts showed a positive correlation separating, on the one side, G. meridionalis and G. cordifolia populations (M-CS and C-FZ), whereas, on the other side, teeth length separated C-VA (G. cordifolia) and, to a lesser degree, M-FV (G. meridionalis). According to the directions of $\mathrm{PC} 2$, which explained $30 \%$ of the total variance, some populations were clearly separated by tube length (M-FI), and both LMA and inner bract lengths (M-MU, M-GP, and M-FV). We also explored PC3 (Supplement 3) that explained 17\% of total variance, but without any relevant discrimination between populations and/or species.

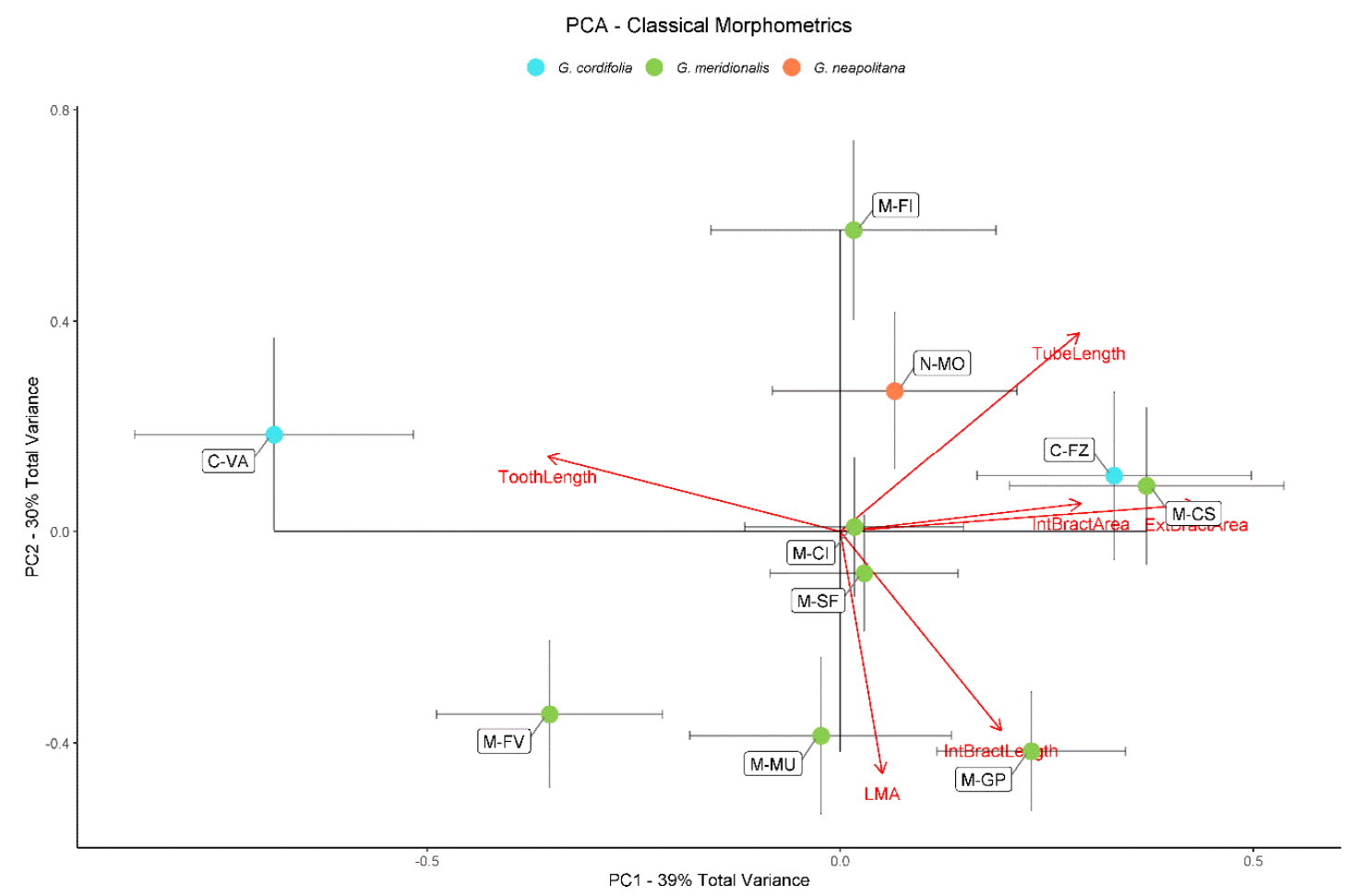

Figure 3. Principal component analysis for classical morphometric data. Red arrows represent loadings along principal component (PC)1 and PC2. Each population (see Table 1) is represented by mean \pm standard error of the mean of the scores along PC1 and PC2 in a different color according to species.

Modelling PC1 for classical morphometrics with environmental predictors showed a good fit, with high values of both explanatory and predictive power after cross-validation $(p<0.050)$ (Table 2). Significant predictors were solar radiation and annual precipitation. Noticeably, there was an inverse trend in both predictors and PC1 scores (Figure 4). Solar radiation was $\geq 14,000 \mathrm{~kJ} / \mathrm{m}^{2} /$ day for most populations, whereas only three populations (C-FZ, M-MU, and M-GP) were below this threshold. The PCA scores for C-VA, M-FV, and M-CS were outliers when correlated with solar radiation. As for annual precipitation, a clearer separation was shown by most population growing below $900 \mathrm{~mm}$, with the exception of M-MU, M-GP, and C-VA. M-FV and M-GP were outlying in the correlation with annual precipitation. The model for $\mathrm{PC} 2$ showed a higher amount of both explanatory and predictive power after cross-validation for a highly significant model $(p<0.010$, Table 2$)$. Temperature seasonality was the only significant predictor, which neatly separated populations such as M-MU, M-FV, and M-GP from all other populations (Figure 5). With the exception of M-FI and M-CI, all populations showed a clear inverse morphometric trend on PC2 with the increase of temperature seasonality. Temperature seasonality above $6.2^{\circ} \mathrm{C}$ correlated with increase in LMA and inner bract length, whereas the opposite was true for calyx teeth length. Both models for PC1 and PC2 in classical morphometrics showed high 
values of concordance correlation coefficient (CCC) and low values of normalized mean absolute error (nMAE), supporting model reliability despite the comparatively low population sample size.

G. cordifolia G. meridionalis $\bigcirc$ G. neapolitana
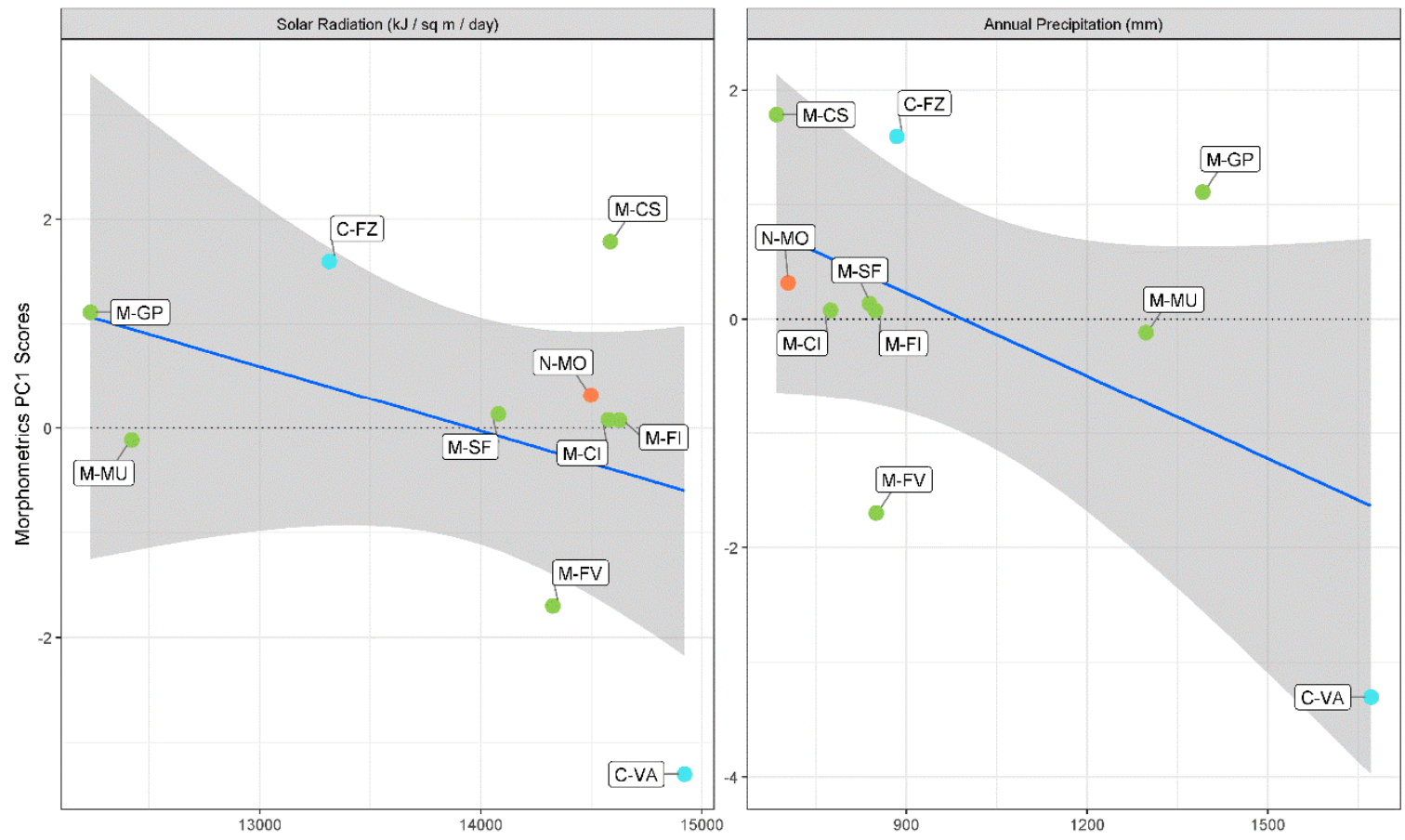

Figure 4. Scatterplot between classical morphometric PC1 scores and significant environmental predictors.

G. cordifolia G. meridionalis G. neapolitana

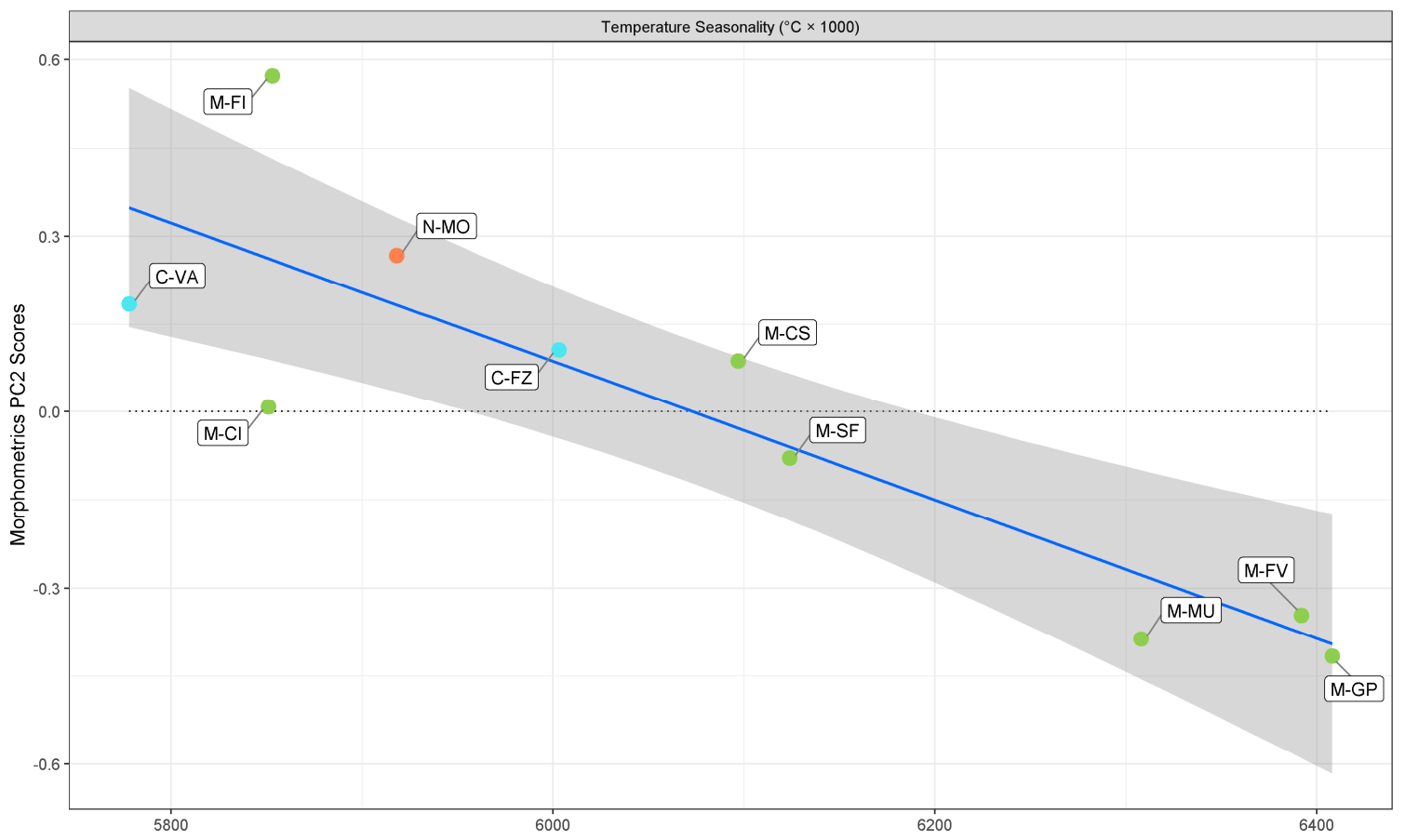

Figure 5. Scatterplot between classical morphometric PC2 scores and temperature seasonality. 
Table 2. Results of the multiple regression models using classical and geometric morphometrics PCs as dependent variables and environmental variables as predictors. $R^{2}{ }_{\mathrm{e}} / R^{2}$ p represent explanatory and predictive power, respectively, whereas CCC/nMAE represent concordance correlation coefficient and normalized mean absolute error, respectively. Symbols represent ${ }^{*} p<0.05$ and ${ }^{*} p<0.01$

\begin{tabular}{|c|c|c|c|c|}
\hline \multirow[b]{2}{*}{ Predictors } & \multicolumn{4}{|c|}{ Dependent Variables } \\
\hline & PC1 Classical Morphometrics & PC2 Classical Morphometrics & $\begin{array}{l}\text { PC1 Geometric } \\
\text { Morphometrics }\end{array}$ & $\begin{array}{l}\text { PC2 Geometric } \\
\text { Morphometrics }\end{array}$ \\
\hline & Estimate (Confidence Interval) & Estimate (Confidence Interval & Estimate (Confidence Interval & Estimate (Confidence Interval \\
\hline (Intercept) & $\begin{array}{c}18.70 \\
(7.91-29.50) *\end{array}$ & $\begin{array}{c}7.16 \\
(4.31-10.02) * *\end{array}$ & $\begin{array}{c}1.20 \\
(0.49-1.91) *\end{array}$ & $\begin{array}{c}-0.01 \\
(-0.03-0.01)\end{array}$ \\
\hline Solar radiation & $\begin{array}{c}-1.10 \times 10^{-3} \\
\left(-1.80 \times 10^{-3} \text { to }-4.00 \times 10^{-4}\right)^{*}\end{array}$ & & & \\
\hline Annual precipitation & $\begin{array}{c}-3.60 \times 10^{-3} \\
\left(-5.60 \times 10^{-3} \text { to }-1.30 \times 10^{-3}\right)^{*}\end{array}$ & & & \\
\hline Temperature seasonality & & $\begin{array}{c}-1.18 \times 10^{-3} \\
\left(-1.65 \times 10^{-3} \text { to }-7.10 \times 10^{-4}\right)^{* *}\end{array}$ & $\begin{array}{c}-2.0 \times 10^{-4} \\
\left(-3.10 \times 10^{-4} \text { to }-8.00 \times 10^{-5}\right)^{*}\end{array}$ & \\
\hline Mean Temperature driest quarter & & & & $\begin{array}{c}8.00 \times 10^{-5} \\
\left(-8.00 \times 10^{-5} \text { to } 1.90 \times 10^{-4}\right) \\
\end{array}$ \\
\hline$R_{\mathrm{e}}^{2} / R_{\mathrm{p}}^{2}$ & $0.697 / 0.545$ & $0.760 / 0.617$ & $0.580 / 0.417$ & $0.179 / 0.000$ \\
\hline CCC/nMAE & $0.683 / 0.212$ & $0.782 / 0.144$ & $0.624 / 0.229$ & $0.000 / 0.377$ \\
\hline
\end{tabular}




\subsection{Geometric Morphometrics}

The multiple regression of shape on size was highly significant $(p=0.002)$, and thus allometry was strongly present. Once size-corrected, results for PCA in geometric morphometrics can be seen in Figure 6. Almost all variance (91\%) is summarized in the first two PCs, with PC1 explaining 85\% of total variance and PC2 explaining $6 \%$. The relative changes in shape according to the direction of $\mathrm{PC} 1$ show that populations from all species (N-MO, M-FI, M-CS, C-VA, and M-CI) are distinguished from all other populations by leaf shape, which was broader than the average shape, whereas leaves from other populations were more elliptical, with strong variations on the position of landmarks 2-10 and 3-9. Although explaining little variance, PC2 showed shovel-shaped or narrow leaves in positive and negative directions, respectively. Leaf apex was also affected by PC2, with rounder vs. pointed tips in the two directions of the axis, without evidence of other apex morphologies (e.g., rounded vs. three-toothed, see Figure 9).

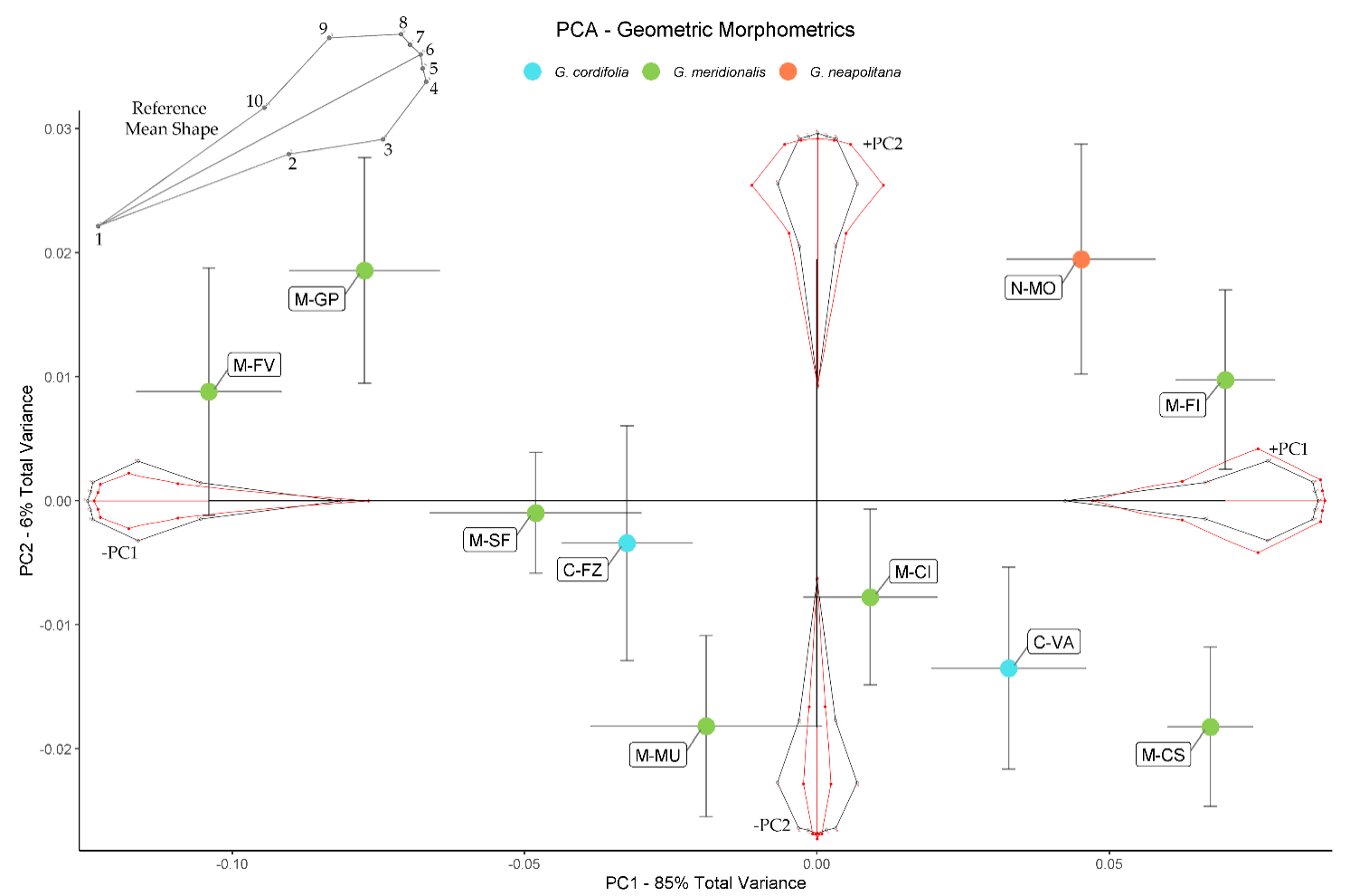

Figure 6. Principal component analysis for geometric morphometric data. Shape variations on each PC and according to the PC sign are shown as exaggerated $\pm 20 \%$ deformations (red) from the reference mean shape (black). A reference mean shape with the position of landmark and semi-landmarks is shown in the upper left corner. Each population is represented by mean \pm standard error of the mean of the scores along PC1 and PC2 in different color according to species.

In line with classical morphometrics, temperature seasonality was the most significant predictor in the model for PC1 in geometric morphometrics (Table 2 and Figure 7). The model, despite a comparatively lower explanatory and predictive power than classical morphometrics, proved to be significant $(p<0.050)$. Leaves from some populations (e.g., M-GP and M-FV) showed a difference in shape from other populations (e.g., C-VA and M-FI), coherent with the reduction in temperature seasonality. Thus, larger temperature seasonality $\left(\geq 6.2^{\circ} \mathrm{C}\right)$ is reflected in narrower leaves, whereas smaller temperature seasonality $\left(\leq 6.0^{\circ} \mathrm{C}\right)$ broadens leaf shape. On the contrary, PC2 model in geometric morphometrics was not significant (Table 2). The only variable included in the model was the mean temperature of driest quarter, showing a weak but not significant positive trend with PC2 
(Supplement 4). The values of CCC and nMAE for the PC1 geometric morphometric model confirmed its reliability after cross-validation.

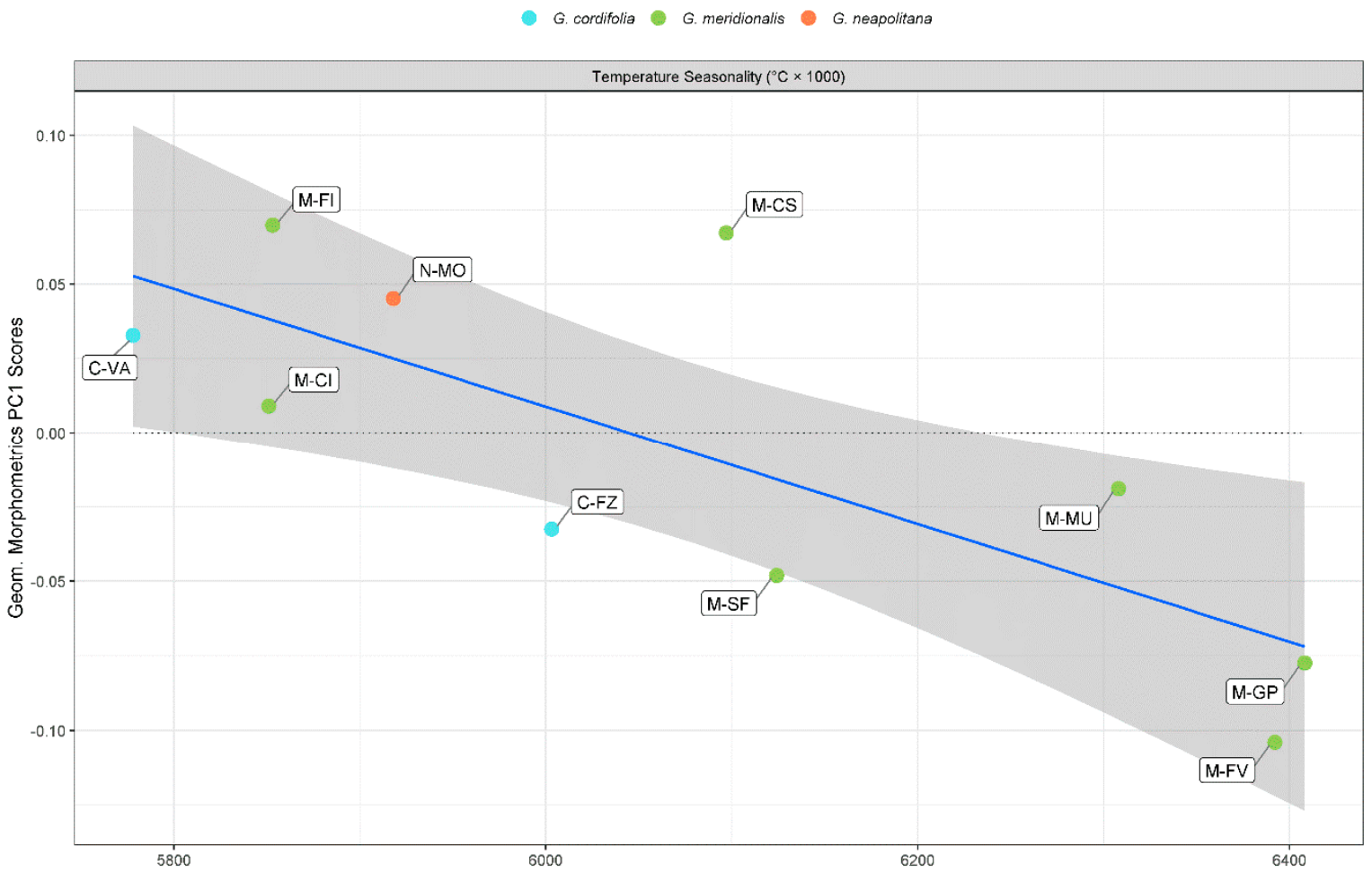

Figure 7. Scatterplot between geometric morphometric PC1 scores and temperature seasonality.

\section{Discussion}

Our morphometric approach confirmed the great variability in G. cordifolia species complex, both in size and shape. A set of morphometric features that would reliably discriminate G. cordifolia, G. meridionalis, and G. neapolitana was not observed, supporting the results from earlier morphological investigations of the same species [6,21,22]. All morphometric variables, when considered at a population level, did not show significant differences, with the exception of LMA. Pignatti [2] suggested that the key diagnostic characteristic is the ratio between calyx teeth and tube, with the tube being much longer in G. cordifolia compared to that in G. meridionalis, in which teeth and tube should be sub-equal, whereas in G. neapolitana, teeth are longer than the tube. Our results did not confirm such a pattern, given that teeth are clearly longer than the tube only for G. cordifolia (C-VA) and G. meridionalis (M-FV, M-MU, M-CI), whereas all other populations showed teeth slightly longer than, or sub-equal to tubes (C-FZ, M-CS, and M-FI). Similarly, Milletti [6] found that the calyx teeth were always longer than the tube, and rarely sub-equal. Concerning the separation of G. cordifolia from G. meridionalis, a distinction on outer bracts was also proposed, specifically on the presence of hairs and the shape of the bracts characterized by the maximum width positioned at the base or at the center of the bract [2]. We did observe the presence of hairs in some populations of G. meridionalis (see Supplement 2), yet with a great degree of variability in abundance, and we agree with Milletti [6] that this character can be deemed unreliable. Outer bracts were reported as strongly mucronate in G. neapolitana [2], a feature that we did notice in most specimens from N-MO (see Supplement 2), although there was no difference in their size compared with those of G. cordifolia and G. meridionalis. Milletti [6] observed that the only true morphological differences existing between G. repens and G. cordifolia concern the leaves not exceeding $2 \times 0.5 \mathrm{~cm}$, always with entire apex, in the former. Conversely, G. meridionalis was considered a heterotypic synonym of G. cordifolia, whereas G. neapolitana was retained as a subspecies of $G$. cordifolia [6,23], being distinguished by leaf shape, that is, lamina from 
spatulate-obovate to suborbicular with crenate-undulate margin vs. lamina from oblanceolate-obovate to spatulate-cuneiform with entire margin [6]. Globularia neapolitana was also reported as bearing nude flowering scapes [6].

On the basis of such a confused taxonomic picture, our novel approach shed new light on the morphological variability in G. cordifolia species complex, showing that ecological predictors could explain both size and shape, revealing an apparent lack of taxonomical differences among species. Most of the variation in size, involving leaf and bract morphological variables, could be explained by a combination of solar radiation, temperature seasonality, and annual precipitation. Among the several available environmental predictors, we found that elevation was not significant in any model. Accordingly, previous evidence showed that elevation could not influence morphology in G. cordifolia [6], although there has been no in-depth study on Globularia morphology on elevation gradients. The evidence from literature highlighted that elevation might cause a variation in a clinal pattern, as was observed with Penstemon sp. pl. [44], or even no variation on strong altitudinal gradients, as observed in Sesleria rigida Heuff. ex Rchb. [45]. In our case, variation on classical morphometric PC1 was shown to be correlated with a combination of solar radiation and annual precipitation, with noticeable changes in flower and receptacle variables. Solar radiation, especially UV-B radiation, can trigger a broad range of responses in plants at the molecular, cellular, and organism level, including the structure of the inflorescences [46,47]. In bromeliads from xeric environments, variations in the shape of the rosette, leaf color, and size of the leaf sheath and blade were shown to be correlated with solar radiation [48]. As for annual precipitation, anatomical differentiation of populations of S. rigida were found to be significantly correlated with annual precipitation and the precipitation of the wettest month, whereas temperatures were not significant [45]. Conversely, there is a general consensus that mean annual temperatures are significantly more strongly correlated with plant traits than mean annual precipitation, although such evidence can be biased due to the weak link between mean annual precipitation and the availability of water to plants [49].

We presented, for the first time, extensive LMA measurements for G. cordifolia species complex. Pierce et al. [50] reported specific leaf area only for G. cordifolia as $6.3 \mathrm{~mm}^{2} \mathrm{mg}^{-1}$. This value corresponds to LMA value of $158.7 \mathrm{~g} / \mathrm{m}^{2}$, which is in line with our measurements. From a life-form perspective, LMA values like those we have found in our samples are reported as typical for evergreen shrubs, although they are overlapping also with evergreen gymnosperms and succulent plants [51]. From an ecological point of view, values of $200 \mathrm{~g} / \mathrm{m}^{2}$ are typical for shrubland or desert species [51]. These data confirm the known ecology and evolutionary history of Globularia section Empetron as adapted to arid rocky xeric environments $[1,5,12]$, but do not contribute to their taxonomy. LMA was shown to be significantly higher for G. meridionalis than the other two species, but LMA was also the driving variable on PC2 for classical morphometrics and PC1 for geometric morphometrics which, in turn, were correlated with temperature seasonality. Temperature seasonality is a measure of temperature change over the course of the year and it is computed as standard deviation of the 12 mean monthly temperature [52]. This variable has been shown to be an important ecological predictor for the distribution of many plant species, either rare or widespread [53-57]. This predictor clearly helped us to distinguish some populations (M-GP, M-MU, and M-FV) that are above $6.2{ }^{\circ} \mathrm{C}$ temperature seasonality, exhibiting the highest values of most morphological variables, as well as also explaining most of the variation in shape. Comparing the values of temperature seasonality with LMA, M-MU, M-SF, and M-FV showed LMA values above $200 \mathrm{~g} / \mathrm{m}^{2}$ and up to $260 \mathrm{~g} / \mathrm{m}^{2}$ for M-GP. According to ecological literature, these LMA values indicate that either drought, nutrient limitation, or both can have a limitative effect on plant growth [51], which can give insights to a morphological adaptation to specific stresses.

We cannot be completely sure on how these morphological variations can be beneficial for the life of Globularia populations as a response of ecophysiology. Undoubtedly, plants can show a surprising degree of morphological plasticity at either small or large scale. As a matter of fact, in two populations of Prunus serotina Ehrh., one from a xeric and one from a mesic environment, sun leaves from the xeric population had greater thickness, specific mass, and guard cell length than the sun leaves from the 
mesic population, yet no morphological difference was found in shade plants in either population [58]. Plants that have evolved in arid environments, such as G. cordifolia, can show morphological changes to environmental modifications at a comparatively fast rate. For instance, two desert shrubs from Central Asia responded to recent increase in precipitation both in their morphology and physiology [59].

Changes in calyx and receptacle size could also reflect changes in pollinators, given that coevolution with pollinators can generate within-species geographic variation in the morphology of plant species, eventually leading to plant speciation [60]. Pollinators can be "drivers" of variation, such as in the case of Arum maculatum L., a widespread species with a specialized pollination system [61]. In this plant and its pollinators (two species of flies), a geographically structured variability in pollinators was found, with increasing proportion of one species with higher annual precipitation and lower precipitation in the warmest trimester, two features typical of the Mediterranean zone [61]. Globularia flowers are bilabiate and protogynous, and observed pollinators have been butterflies, bees, beetles, and syrphids $[6,62,63]$, although detailed study on pollinators in this genus, especially in G. cordifolia species complex or along elevation gradients, are scarce and outdated [64]. Thus, it cannot be ruled out that the trends in calyx and receptacle morphology can be a consequence of a shift in pollinators on climatic gradients.

Our study on size was accompanied by a geometric morphometrics approach on leaves. Our test for allometry showed that there was a strong effect of size onto shape. Allometry can be a pivotal component of shape variation, and generalized procrustes analysis (GPA) removes isometric effects of size on shape, but not allometric effects [65]. Thus, our approach of performing shape analysis on size-corrected shapes allowed us to interpret only the variation on shape once allometric affects have been taken into account $[66,67]$. Given the lower amount of variation of modelling with PC1 of geometric morphometrics, the variation of shape was smaller than size and less correlated with ecological predictors. We found that temperature seasonality can explain most of the variations in shape, in the same way as it explained variation in PC2 for classical morphometrics. Leaf shape variations have been shown to be a functional response to altitude and longitude at regional scales rather than to temperature-related factors such as latitude [68]. Environmental gradients in shapes, with special regard to elevation, were also found in Sophora davidii Franch., providing strong evidence that variations in morphological and genetic parameters reflect morphological and genetic adaptation to native habitats, highlighting ecological and evolutionary consequences along altitudinal gradients of mountainous ecosystems [69]. The shape of the leaf apex was widely indicated in the past as diagnostic $[2,15,70]$. Nevertheless, the shape of the leaf apex (rounded vs. mucronate vs. three-toothed) has been considered a largely inconstant character, greatly varying among and within populations (see Figure 9) [6,21,22]. Ravnik [21,22] also reported that different leaf shapes, that, according to Schwarz [3] are characteristic for G. cordifolia or G. meridionalis, can be present in a single plant at the same time. We found no relevant variation in the leaf-apex landmarks in our shape analysis.

Despite a relatively small sample size compared to the area of occurrence of the studied plants, which might limit the breadth of this research, we provided evidence that the variability in size and shape within G. cordifolia species complex could be connected to environmental factors. Accordingly, we did not observe any reliable morphological pattern that would support the current classification into different species, albeit our research was ecologically oriented and not a taxonomic study. Admittedly, the observed absence of morphological evidence that would support current classification G. cordifolia species complex might simply be a consequence of low statistical power due to our insufficient sample size, along with the underrepresentation of G. cordifolia (two samples) and the narrow endemic G. neapolitana (one sample). Nevertheless, our analysis was supported by an underlying large sample size per individuals as well as robust evidence from cross-validation of the models.

Moreover, it should be noted that lack of characteristics that would support the separation of G. cordifolia and G. meridionalis into different species was recently recorded by Friščić [71], who studied different aspects of Globularia species from Croatia. On the basis of molecular [1,5], phytochemical $[18,72,73]$, and karyological data [6,22,71], as well as previous morphological 
data [6,21,22], G. meridionalis formed a continuum with G. cordifolia and might be considered without any taxonomical value as indicated also by earlier studies of plant material from Italy, Slovenia, Croatia, Bosnia and Herzegovina, Serbia, and Macedonia [6,21-24]. Concerning G. neapolitana, the single population that we sampled (N-MO) falls within the same morphological pattern, and might therefore be included as a heterotypic synonym of G. cordifolia. On the basis of our evidence, the reported sympatry between G. meridionalis and G. neapolitana [30] would be unrealistic. According to molecular data, G. neapolitana forms a single lineage with G. cordifolia, with the only difference that possible ancestral ranges for G. cordifolia should be from the Circumboreal Region, whereas G. neapolitana belongs to the Mediterranean basin [5]. Nevertheless, literature data suggest that a population referred as G. neapolitana from the island of Capri, given its isolation and low-elevation, shows morphological differences substantiating its taxonomic position as a distinct unit [6]. Such peculiarity is confirmed by anomalies in the chromosome counts and by cultivation experiments, where plants retained their morphology, suggesting a genetic stabilization of characters [6,23]. A herbarium sheet by G. Gussone dating back to 1808 is present in the Herbarium Neapolitanum (NAP!). The original label refers to G. bellidifolia Ten. with a vague geographical reference to Capri, with no indication of precise toponyms. The sheet was later revised by M. Ricciardi in 1976, who identified the samples as G. neapolitana. The conservation status of the herbarium sheet, the low number of organs, and the impossibility of evaluating clone sampling prevented us from considering this herbarium sheet in our analysis. Despite field research, we were unable to retrieve any Globularia populations in Capri, but we cannot exclude that, at least in this population, there could be a patroendemic systematic unit [74].

Given its ploidy level, recent origin, and distribution, G. cordifolia is likely a result of glaciations [12]. Polyploid species are favored under stressful environmental conditions [75], and patterns of morphological clines within and among plant species are known in the Mediterranean basin, as in the case of Pinguicula [76], Soldanella [77], Fritillaria [78], and other mountain-Mediterranean taxa, including Globularia sp. pl. from other sections besides G. section Empetron $[5,13,14]$. Although there is a need for a larger scale genetic and morphometric analysis in G. cordifolia species complex [1], along with an in-depth cultivation study to assess if there is a potential genetic basis for plant traits [79] and/or any effect of soil, our morphological analysis, along with ecological statistics, helped to bring about a new perspective this puzzling group of species.

\section{Conclusions}

According to our results, the variability in size and shape within G. cordifolia species complex could be explained by environmental variables, such as temperature seasonality. A reliable pattern that would go in favor of the classification into three distinguished species, namely, G. cordifolia, G. meridionalis, and G. neapolitana, was not observed in this study, although definitive taxonomic implications fall behind the scope of this research. Acknowledging the relatively small sample size of populations and the fact that samples were collected only from a limited geographical area (Italy and Croatia), it would be desirable to further expand the study on populations from a wider distribution area and verify, not only by means of morphometrics but also by DNA-based analysis including common garden experiments, whether the current classification into different species is justifiable or not. Nevertheless, we provided evidence that the environment might have been the main driver behind the large morphological variability in G. cordifolia species complex, which has confused taxonomists for more than 150 years.

\section{Materials and Methods}

\subsection{Sample Collection}

We sampled 10 different populations of G. cordifolia species complex (Figure 1) from a wide part of its area of occurrence (Table 3 and Figure 2), with a minimum distance between populations of $15 \mathrm{~km}$ (M-CS vs. M-CI) and a maximum of $979 \mathrm{~km}$ (C-VA vs. M-FI, see Figure 2). The identification of the 
populations, according to current nomenclature and known distributions, was performed following the methods in [2,3]. We focused on G. cordifolia, G. meridionalis, and G. neapolitana, given that G. repens had been previously shown to be clearly separated from other species of $G$. section Empetron on many levels $[1,5,6]$. Between June and October 2017, 11-16 specimens per population were collected. Individual plants were chosen as being at least $5 \mathrm{~m}$ apart, in order to reduce the risk of clone-sampling, and a branch with its flowering scapes was cut from the plant. All samples were dried and kept on herbarium sheets until processing. A high-resolution digital version of voucher specimens is presented in Supplement 5. At the sampling time, most populations were bearing fruits and not flowers. However, calyces persist after flowering, whereas corollas have been shown to have no diagnostic power [6], especially considering that tentative differences can be appreciated only on fresh specimens but not on dried ones [2]. Similarly, bracts along the flowering scape (i.e., scales) were deemed unreliable both in their number and their morphology according to the literature [4,6]. According to the conservation status of the different specimens within the population and the availability of intact organs, we performed measurements on 674 leaves (i.e., between 4 and 6 leaves per specimen), 351 calyces (i.e., 1-6 calyces per specimen), 86 external bracts (i.e., 1-3 bracts per specimen), and 196 internal bracts (i.e., $1-4$ bracts per specimens). All organs were randomly chosen on each specimen in order to account for their variability, avoiding organs that were damaged or clearly under development. Nevertheless, the means per individuals within each population, followed by grand mean per population, were used for the statistical analyses. A complete imagery and data collection from all individuals is available as Supplement 2. 
Table 3. Sampled populations, with their ID, name, region, and country. Populations are sorted according to species and latitude, from north to south. The identification of each species was performed according to the morphological description and distribution reported by [2,3]. Altitude is given as $\mathrm{m}$ above sea level, whereas geographic coordinates (latitude and longitude) are in decimal degrees (WGS-84).

\begin{tabular}{|c|c|c|c|c|c|c|}
\hline ID & Description & Species & Date of Collection & Elevation & Latitude & Longitude \\
\hline C-VA & Val de Rhêmes, Vallée d’Aoste, Italy & G. cordifolia & 13 July 2017 & 2428 & 45.51 & 7.08 \\
\hline C-FZ & Campocecina-Fivizzano, Toscana, Italy & G. cordifolia & 24 July 2017 & 1293 & 44.11 & 10.15 \\
\hline M-GP & Grobničko polje, Primorje-Gorski kotar, Croatia & G. meridionalis & 8 October 2017 & 308 & 45.38 & 14.51 \\
\hline M-MU & Mala Učka, Primorje-Gorski kotar, Croatia & G. meridionalis & 8 October 2017 & 926 & 45.30 & 14.19 \\
\hline M-SF & Monte S. Franco, Abruzzo, Italy & G. meridionalis & 1 August 2017 & 1647 & 42.46 & 13.41 \\
\hline M-FV & Fonte Vedice, Abruzzo, Italy & G. meridionalis & 24 October 2017 & 1080 & 42.34 & 13.58 \\
\hline $\mathrm{M}-\mathrm{CI}$ & Monte Cigno, Campania, Italy & G. meridionalis & 8 October 2017 & 360 & 41.30 & 14.54 \\
\hline $\mathrm{M}-\mathrm{CS}$ & Camposauro, Campania, Italy & G. meridionalis & 25 June 2017 & 1182 & 41.18 & 14.60 \\
\hline M-FI & Timpa del Principe-Frascineto, Calabria, Italy & G. meridionalis & 8 August 2017 & 1668 & 39.87 & 16.27 \\
\hline $\mathrm{N}-\mathrm{MO}$ & Monte S. Angelo a Tre Pizzi, Campania, Italy & G. neapolitana & 16 July 2017 & 1385 & 40.65 & 14.50 \\
\hline
\end{tabular}




\subsection{Classical Morphometrics}

Individual specimens per population were scanned at high resolution (1200 dpi) with a metric reference (see also Supplement 2). An example specimen, with all measured organs, is shown in Figure 8. According to the literature, we collected morphometric data on calyces (Figure 8b), inner and outer bracts (Figure $8 \mathrm{c}-\mathrm{d}$ ), and leaves (Figure 8e) [2,6]. In detail, we measured 17 variables, namely, (a) area $\left(\mathrm{mm}^{2}\right)$, length $(\mathrm{mm})$, width $(\mathrm{mm})$, length/width ratio, dry weight $(\mathrm{mg})$, and leaf dry mass per unit area (LMA; $\left.\mathrm{g} / \mathrm{m}^{2}\right)$ for leaves; (b) area $\left(\mathrm{mm}^{2}\right)$, length $(\mathrm{mm})$, width $(\mathrm{mm})$, and length/width ratio for inner bracts; (c) area $\left(\mathrm{mm}^{2}\right)$, length $(\mathrm{mm})$, width $(\mathrm{mm})$, and length/width ratio for outer bracts; and (d) tube length $(\mathrm{mm})$, teeth length $(\mathrm{mm})$, and teeth/tube length ratio for calyces. All morphometric measurements were performed using the tps series of software (https://life.bio.sunysb.edu/ee/rohlf/software.html) [80], with the exception of leaf dry weight, hich was measured using an analytical balance (precision 0.001 $\mathrm{mg}$ ). Leaf dry mass per unit area (LMA) was calculated according to [81].

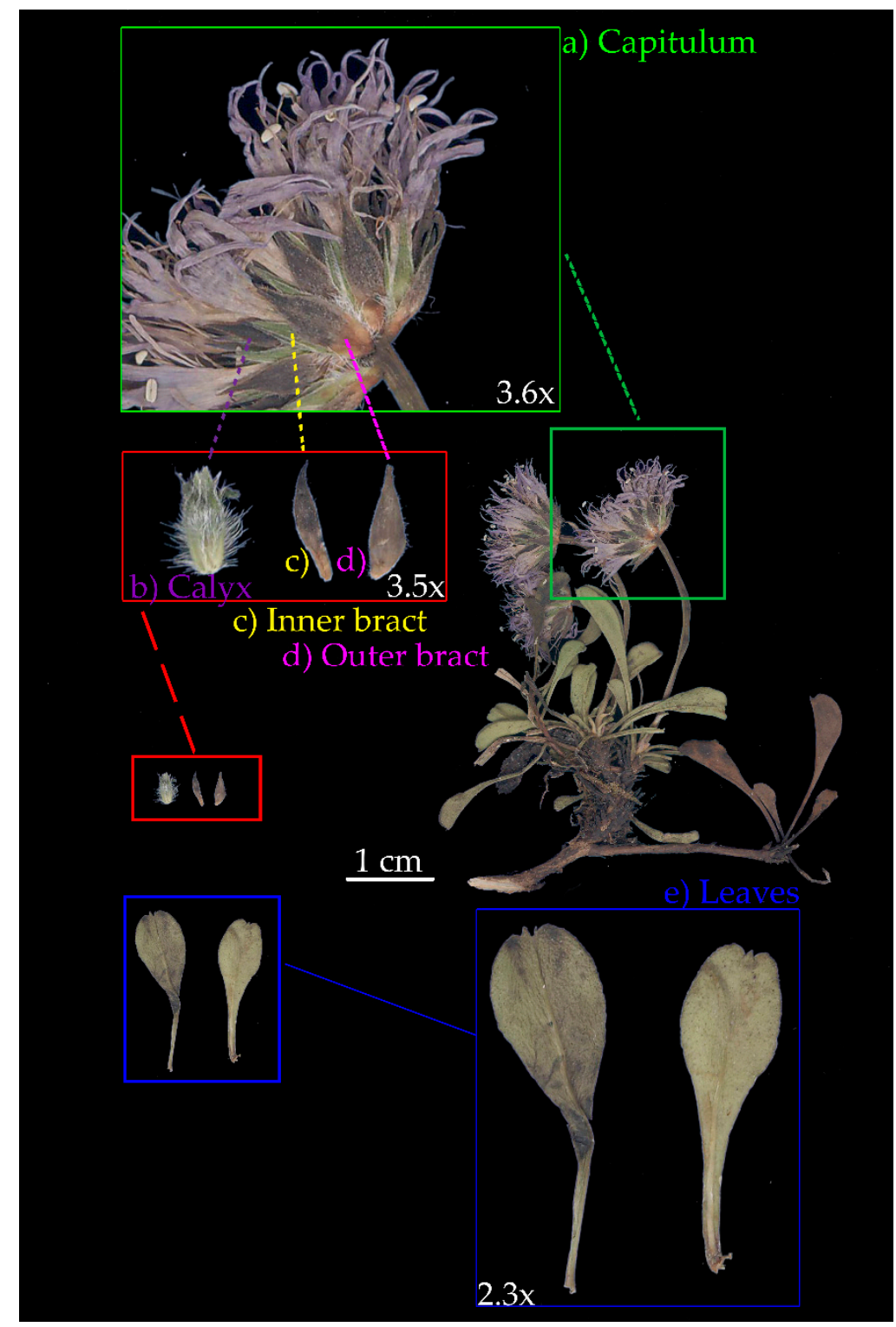

Figure 8. Details of a branch from Globularia cordifolia (Val de Rhêmes, Vallée d'Aoste, Italy). The inflorescence (a) (capitulum) is shown in the green box at 3.6× magnification. Details of the calyx (b), inner (c), and outer bracts (d) are shown in the red box at $3.5 \times$ magnification. Leaves (e) are shown in the blue box at $2.3 \times$ magnification. 


\subsection{Geometric Morphometrics}

Leaves were also analyzed using a geometric morphometric approach. We used generalized procrustes analysis (GPA) as a superimposition method, considering the objects as symmetric [82]. GPA is an established procedure for analysis of 2D and 3D shapes, which has been widely applied to plants in the last years [83-88]. Although objects such as leaves can be analyzed also by means of elliptical Fourier analysis [89], we decided that a landmark approach was more suited to detect possible subtle changes with potential diagnostic value, such as those considering the morphology of leaf apex. We opted for a configuration of 10 landmarks, designed to represent the putative diagnostic features that were reported during the years (Figure 9). Landmarks 1 and 6 represent petiole and leaf tips, respectively; 2 and 10 are the points where the blade begins to expand; 3 and 9 represent maximum width; and points 4 and 5, and 7 and 8 are semi-landmarks [90] to describe the shape of the leaf apex, which has been reported as diagnostic by several authors $[2,15,70]$. Please note the detail in Figure 9 that depicts the configuration of the latter landmarks, designed to detect the large variability in leaf apex from rounded to three-toothed. Landmarks were digitized using software from the tps series [80]. Digitizing was performed with tpsDig and repeated twice after two weeks on a random subsample of pictures in order to assess the error in digitizing, which was around $2-3 \%$. After digitizing, GPA was performed in MorphoJ [91]. In order to account for allometric effects, we performed a multivariate regression of shape onto size using the natural logarithm of centroid size of every shape as an independent variable. Thus, the residuals of this regression can be considered as "size-corrected" shapes, permitting a better interpretation of the variations in shape once size has been taken into account $[67,86]$.

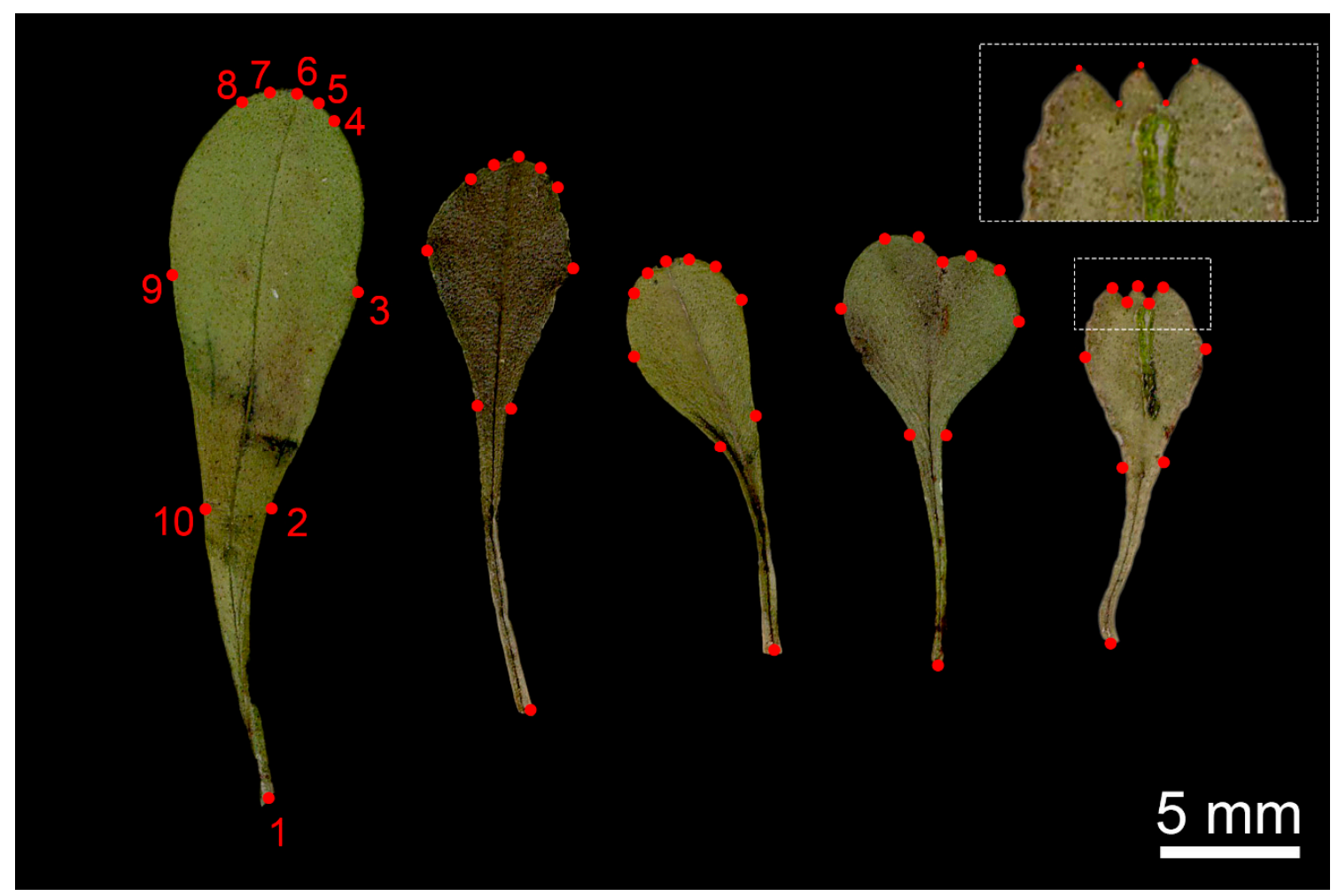

Figure 9. Morphometric gradient in leaves from G. meridionalis with landmark configuration. From left to right, a gradient in size and shape is shown, especially in the leaf apex from rounded to three-toothed. Landmark description: 1 and 6, petiole and leaf tips; 2 and 10, points where the blade begins to expand; 3 and 9, points of maximum width; 4 and 5 , and 7 and 8 , semilandmarks to describe the shape of the leaf apex (details are shown in the box). 


\subsection{Statistics and Modeling}

All data were inspected for outliers by creating sub-datasets per population and performing principal component analysis (PCA). All specimens exceeding a 95\% ellipse of the distribution in the scatterplot of the first two components were considered outliers and excluded from further analyses [86]. Given the large degree of collinearity in morphometrics [67], we reduced the number of variables in the classical morphometric dataset to weakly correlated variables, recursively excluding those that were strongly correlated (Pearson's correlation coefficient $\geq|0.85|$ ). The procedure retained LMA, calyx tube and teeth lengths, outer bract area, and inner bract length and area. After this procedure, minimum correlation was $r=0.11$ and maximum was $r=-0.64$. Differences among populations or species were tested by one-way ANOVA. Data were transformed by Box-Cox transformation with optimal lambda to ensure normality and homogeneity of variances [92]. Multiple comparisons were performed by Games-Howell post-hoc test $(\alpha=0.05)$. On both classical and geometric morphometric datasets, we performed PCA. Scores for the first two PCs were extracted and used as dependent variables for ecological modelling [93-96]. Geographical and bioclimatic variables at $1 \times 1 \mathrm{~km}$ spatial resolution were obtained from www.worldclim.org [36] and used as predictors in the modelling procedure. Predictors included latitude, longitude, elevation, solar radiation, wind speed, water vapor pressure, and 19 bioclimatic variables (bio_01-bio_19) derived from temperature and precipitation [52]. To avoid multicollinearity in the predictors, bioclimatic variables were selected using a variance inflation factor (VIF) approach by recursively dropping all variables with VIF $\geq 3[55,56]$. The procedure retained elevation, solar radiation, bio_04 (temperature seasonality), bio_09 (mean temperature of driest quarter), and bio_12 (annual precipitation). We tested the presence of spatial autocorrelation by means of Moran's I coefficients [97,98], but we found no evidence of it in all cases. Subsequently, we fitted multiple linear regressions with Akaike Information Criterion based stepwise backward selection of the predictors [99]. In order to test for possible overfitting problems and to validate the results, we used leave-on-out cross-validation [100] The goodness of fit of each model was assessed as explanatory $\left(R_{\mathrm{e}}^{2}\right)$ and predictive power $\left(R_{\mathrm{p}}^{2}\right)$ after cross-validation [101]. The cross-validated models were also evaluated for their accuracy and precision by normalized mean absolute error (nMAE) [102] as well as concordance correlation coefficient (CCC) [103]. The presence of non-linear patterns in the model residuals was tested by fitting a generalized additive model (GAM) [104] between the model residuals and the covariates, respectively [101]. All statistical analyses were performed in R 3.6.0 [105].

Supplementary Materials: The following are available online at http://www.mdpi.com/2223-7747/9/3/314/s1, Supplement 1: All classical morphometric measurements for the studied populations. Values are mean \pm standard error of the mean. Supplement 2: Complete imagery and data for classical and geometric morphometric analyses. Supplement 3: PC2 vs. PC3 for classical morphometric data. Supplement 4: Scatterplots between geometric morphometric PC2 scores and mean temperature of driest quarter. Supplement 5: High resolution digital voucher specimens for all sampled populations.

Author Contributions: Conceptualization, M.I. and K.H.P.; formal analysis, M.I. and T.D.; funding acquisition, M.I. and A.F.; investigation, M.I, M.F., F.C., F.B., and L.P; methodology, M.I.; resources, M.I., M.F., T.D., F.C., F.B., A.F., and L.P.; supervision, M.I., A.F., and L.P.; visualization, M.I.; writing-original draft, M.I.; writing-review and editing, M.I, M.F., T.D., F.C., F.B., A.F., and L.P. All authors have read and agreed to the published version of the manuscript.

Funding: This research received no external funding.

Acknowledgments: This work is dedicated to the memory of Prof. Kroata Hazler Pilepić, who actively promoted the international collaboration between Croatia and Italy for studying different aspects of Globularia. The authors are grateful to Maria Teresa Palomba for her contribution in processing and digitizing the plant materials, to Mirko Di Febbraro for his constructive counselling, and to the Herbarium Neapolitanum (NAP) and Olga De Castro at the Department of Biology of the University of Naples Federico II for their collaboration.

Conflicts of Interest: The authors declare no conflicts of interest. 


\section{References}

1. Hazler Pilepić, K.; Friščić, M.; Duran, A.; Maslo, S.; Garić, R.; Čuljak, S.; Šutalo, K. Contribution to Globularia phylogeny based on nuclear ribosomal spacer and two chloroplast DNA regions. Period. Biol. 2016, 118, 417-424. [CrossRef]

2. Pignatti, S. Flora d'Italia; Edagricole: Firenze, Italy, 2019; Volume 3, ISBN 8850652429.

3. Schwarz, O. Die Gattung Globularia. Bot. Jahrb. Syst. 1938, 69, 318-373.

4. Holländer, K.; Jäger, E.J. Morphologie, Biologie und ökogeographische Differenzierung von Globularia: I. Progessionen in der Wuchsform, Infloreszenz, Blattnervatur und Verbreitung. Flora 1994, 189, $223-254$. [CrossRef]

5. Affenzeller, M.; Kadereit, J.W.; Comes, H.P. Parallel bursts of recent and rapid radiation in the Mediterranean and Eritreo-Arabian biodiversity hotspots as revealed by Globularia and Campylanthus (Plantaginaceae). J. Biogeogr. 2018, 45, 552-566. [CrossRef]

6. Milletti, N. Revisione sistematica del genere Globularia L. (Globulariaceae) in Italia. Ph.D. Thesis, University of Florence, Florence, Italy, 1987.

7. Duman, H. A new species of Globularia L. (Globulariaceae) from South Anatolia. Bot. J. Linn. Soc. 2001, 137, 425-428. [CrossRef]

8. APG. An update of the Angiosperm Phylogeny Group classification for the orders and families of flowering plants: APG IV. Bot. J. Linn. Soc. 2016, 181, 1-20. [CrossRef]

9. Schwarz, O. Chromosomenzahlen, Lebensformen und Evolution der Gattung Globularia L. Drudea 1963, 3, 5-16.

10. Contandriopoulos, C. Contribution a l'etude cytobiogeographique du genre Globularia L. Biol. Ecol. Medit 1978, 5, 3-14.

11. Kadereit, J.W.; Griebeler, E.M.; Comes, H.P. Quaternary diversification in European alpine plants: Pattern and process. Philos. Trans. R. Soc. B Biol. Sci. 2004, 359, 265-274. [CrossRef]

12. Comes, H.P.; Kadereit, J.W. Tests of Pleistocene speciation among alpine and montane species of Globularia (Globulariaceae) from the European high mountains. Bauhinia 2001, 15, 76.

13. Kadereit, J.W.; Comes, H.P. The temporal course of alpine plant diversification in the Quaternary. Regnum Veg. 2005, 143, 117-130.

14. Comes, H.P.; Kadereit, J.W. Spatial and temporal patterns in the evolution of the flora of the European Alpine System. Taxon 2003, 52, 451-462. [CrossRef]

15. Hegi, G. Scrophulariaceae, Orobanchaceae, Lentibulariaceae, Globulariaceae, Plantaginaceae. In Illustrierte Flora von Mitteleuropa; Carl Hanser Verlag: München, Germany, 1974; Volume VI/1, pp. 551-558.

16. De Natale, A.; Pollio, A. A forgotten collection: The Libyan ethnobotanical exhibits (1912-1914) by A. Trotter at the Museum O. Comes at the University Federico II in Naples, Italy. J. Ethnobiol. Ethnomed. 2012, 8, 4. [CrossRef]

17. Johnson, T. CRC Ethnobotany Desk Reference; CRC Press: Boca Raton, FL, USA, 2018; ISBN 9781315891842.

18. Friščić, M.; Maslo, S.; Garić, R.; Maleš, Ž.; Hazler Pilepić, K. Comparative analysis of specialized metabolites and antioxidant capacity in vitro of different natural populations of Globularia spp. Acta Bot. Croat. 2018, 77, 1-9. [CrossRef]

19. Mateos, M.A.; Valdés, B. A new species of Globularia (Globulariaceae) from the Talassemtane National Park, N Morocco. Willdenowia 2006, 36, 409-412. [CrossRef]

20. Duran, A.; Cetin, Ö.; Öztürk, M. Globularia anatolica sp. nov. (Globulariaceae) from the Honaz Mountain National Park, southwest Turkey. Nord. J. Bot. 2009, 27, 232-237. [CrossRef]

21. Ravnik, V. Zur morphologischen und taxonomischen Problematik von Globularia cordifolia L. im Bereiche der sudostlichen Kalkalpen und des illyrischen Übergangsgebietes. lahrb. Ver. Schutze Alpenpfl. Tiere 1962, 27, 119-121.

22. Ravnik, V. Zur morphologisch-systematischen und chorologischen Problematik der Art Globularia cordifolia L. s. lat. Razpr. Slov. Akad. Znan. Umet. Razred Prir. Med. Vede 1965, 8, 5-41.

23. Milletti, N.; Mori, B. Números Cromosomáticos de Plantas Occidentales, 466-471. An. Jardín Botánico Madrid 1988, 45, 267-272.

24. Milletti, N.; Strid, A. Globulariaceae. In Mountain Flora of Greece; Strid, A., Tan, K., Eds.; Cambridge University Press: Cambridge, UK, 1991; pp. 257-259. 
25. Bartolucci, F.; Peruzzi, L.; Galasso, G.; Albano, A.; Alessandrini, A.; Ardenghi, N.M.G.; Astuti, G.; Bacchetta, G.; Ballelli, S.; Banfi, E.; et al. An updated checklist of the vascular flora native to Italy. Plant Biosyst. 2018, 152, 179-303. [CrossRef]

26. Innangi, M.; Izzo, A.; La Valva, V. Revisione dello status IUCN per alcuni taxa inclusi nella Lista Rossa della Regione Campania. Delpinoa 2007, 49, 77-88.

27. Caputo, G.; La Valva, V.; Nazzaro, R.; Ricciardi, M. La flora della Penisola Sorrentina (Campania). Delpinoa 1990, 31-32, 3-97.

28. Caneva, G.; Cancellieri, L. il Paesaggio Vegetale della Costa d'Amalfi; Gangemi: Roma, Italy, 2007.

29. Guarino, C.; Napolitano, F. Community habitats and biodiversity in the Taburno-Camposauro Regional Park. Woodland, rare species, endangered species and their conservation. Forest 2006, 3, 527-541. [CrossRef]

30. Corazzi, G. Contributo alla conoscenza della flora del Sannio: Il complesso montuoso del Camposauro (Benevento, Campania). Webbia 2008, 63, 215-250. [CrossRef]

31. Larsen, K. Cytological observations on some species of Globularia. Bot. Not. 1957, 110, 265-270.

32. Willkomm, M. Récherches sur l'organographie et la Classification des Globulariées; Gustav Mayer: Leipsick, Germany, 1850.

33. Perrone, R.; Salmeri, C.; Brullo, S.; Colombo, P.; De Castro, O. What do leaf anatomy and micro-morphology tell us about the psammophilous Pancratium maritimum L. (Amaryllidaceae) in response to sand dune conditions? Flora Morphol. Distrib. Funct. Ecol. Plants 2015, 213, 20-31. [CrossRef]

34. Schoettle, A.W.; Rochelle, S.G. Morphological variation of Pinus flexilis (Pinaceae), a bird-dispersed pine, across a range of elevations. Am. J. Bot. 2000, 87, 1797-1806. [CrossRef]

35. Campbell, D.R.; Powers, J.M. Natural selection on floral morphology can be influenced by climate. Proc. R. Soc. B Biol. Sci. 2015, 282, 1-7. [CrossRef]

36. Fick, S.E.; Hijmans, R.J. WorldClim 2: New 1-km spatial resolution climate surfaces for global land areas. Int. J. Climatol. 2017, 37, 4302-4315. [CrossRef]

37. Warton, D.I.; McGeoch, M.A. Technical advances at the interface between ecology and statistics: Improving the biodiversity knowledge generation workflow. Methods Ecol. Evol. 2017, 8, 396-397. [CrossRef]

38. Henderson, A. Traditional morphometrics in plant systematics and its role in palm systematics. Bot. J. Linn. Soc. 2006, 151, 103-111. [CrossRef]

39. Niinemets, Ü.; Kull, K. Leaf weight per area and leaf size of 85 Estonian woody species in relation to shade tolerance and light availability. For. Ecol. Manage. 1994, 70, 1-10. [CrossRef]

40. Smith, W.K.; Vogelmann, T.C.; DeLucia, E.H.; Bell, D.T.; Shepherd, K.A. Leaf Form and Photosynthesis. Bioscience 1997, 47, 785-793. [CrossRef]

41. Cardini, A.; Loy, A. Virtual Morphology and Evolutionary Morphometrics in the new millenium. Hystrix 2013, 24, 1-5.

42. Musarella, C.M.; Cano-Ortiz, A.; Piñar Fuentes, J.C.; Navas-Ureña, J.; Pinto Gomes, C.J.; Quinto-Canas, R.; Cano, E.; Spampinato, G. Similarity analysis between species of the genus Quercus L. (Fagaceae) in southern Italy based on the fractal dimension. PhytoKeys 2018, 113, 79-95. [CrossRef] [PubMed]

43. Zhang, X.; Zhao, W.; Luo, H.; Chen, L.; Peng, J.; Fan, J. Plant recognition via leaf shape and margin features. Multimed. Tools Appl. 2019, 78, 27463-27489. [CrossRef]

44. Kimball, S. Links between floral morphology and floral visitors along an elevational gradient in a Penstemon hybrid zone. Oikos 2008, 117, 1064-1074. [CrossRef]

45. Kuzmanović, N.; Šinžar-Sekulić, J.; Lakušić, D. Ecologically Determined Variation in Leaf Anatomical Traits of Sesleria rigida (Poaceae) in Serbia-Multivariate Morphometric Evidence. Folia Geobot. 2012, 47, 41-57. [CrossRef]

46. Koti, S.; Reddy, K.R.; Kakani, V.G.; Zhao, D.; Reddy, V.R. Soybean (Glycine max) pollen germination characteristics, flower and pollen morphology in response to enhanced ultraviolet-B radiation. Ann. Bot. 2004, 94, 855-864. [CrossRef]

47. Robson, T.M.; Klem, K.; Urban, O.; Jansen, M.A.K. Re-interpreting plant morphological responses to UV-B radiation. Plant Cell Environ. 2015, 38, 856-866. [CrossRef]

48. Rodrigues Pereira, T.A.; da Silva, L.C.; Azevedo, A.A.; Francino, D.M.T.; dos Santos Coser, T.; Pereira, J.D. Leaf morpho-anatomical variations in Billbergia elegans and Neoregelia mucugensis (Bromeliaceae) exposed to low and high solar radiation. Botany 2013, 91, 327-334. [CrossRef] 
49. Moles, A.T.; Perkins, S.E.; Laffan, S.W.; Flores-Moreno, H.; Awasthy, M.; Tindall, M.L.; Sack, L.; Pitman, A.; Kattge, J.; Aarssen, L.W.; et al. Which is a better predictor of plant traits: Temperature or precipitation? J. Veg. Sci. 2014, 25, 1167-1180. [CrossRef]

50. Pierce, S.; Brusa, G.; Vagge, I.; Cerabolini, B.E.L.L. Allocating CSR plant functional types: The use of leaf economics and size traits to classify woody and herbaceous vascular plants. Funct. Ecol. 2013, 27, 1002-1010. [CrossRef]

51. Poorter, H.; Niinemets, Ü.; Poorter, L.; Wright, I.J.; Villar, R. Causes and consequences of variation in leaf mass per area (LMA): A meta-analysis. New Phytol. 2009, 182, 565-588. [CrossRef]

52. O'Donnell, M.S.; Ignizio, D.A. Bioclimatic Predictors for Supporting Ecological Applications in the Conterminous United States. U.S Geol. Surv. Data Ser. 2012, 691, 10.

53. Lomba, A.; Pellissier, L.; Randin, C.; Vicente, J.; Moreira, F.; Honrado, J.; Guisan, A. Overcoming the rare species modelling paradox: A novel hierarchical framework applied to an Iberian endemic plant. Biol. Conserv. 2010, 143, 2647-2657. [CrossRef]

54. Elith, J.; Kearney, M.; Phillips, S. The art of modelling range-shifting species. Methods Ecol. Evol. 2010, 1, 330-342. [CrossRef]

55. Innangi, M.; D'Alessandro, F.; Fioretto, A.; Di Febbraro, M. Modeling distribution of Mediterranean beech forests and soil carbon stock under climate change scenarios. Clim. Res. 2015, 66, 25-36. [CrossRef]

56. De Castro, O.; Di Maio, A.; Di Febbraro, M.; Imparato, G.; Innangi, M.; Vela, E.; Menale, B. A multi-faceted approach to analyse the effects of environmental variables on geographic range and genetic structure of a perennial psammophilous geophyte: The case of the sea daffodil Pancratium maritimum L. in the mediterranean basin. PLoS ONE 2016, 11, e0164816. [CrossRef]

57. Brus, D.J.; Hengeveld, G.M.; Walvoort, D.J.J.; Goedhart, P.W.; Heidema, A.H.; Nabuurs, G.J.; Gunia, K. Statistical mapping of tree species over Europe. Eur. J. For. Res. 2011, 131, 145-157. [CrossRef]

58. Abrams, M.D.; Kloeppel, B.D.; Kubiske, M.E. Ecophysiological and morphological responses to shade and drought in two contrasting ecotypes of Prunus serotina. Tree Physiol. 1992, 10, 343-355. [CrossRef] [PubMed]

59. Xu, H.; Li, Y.; Xu, G.; Zou, T. Ecophysiological response and morphological adjustment of two Central Asian desert shrubs towards variation in summer precipitation. Plant Cell Environ. 2007, 30, 399-409. [CrossRef] [PubMed]

60. Pellissier, L.; Alvarez, N.; Guisan, A. Pollinators as drivers of plant distribution and assemblage into communities. In Evolution Plant-Pollinator Relationships; Cambridge University Press: Cambridge, UK, 2012; pp. 392-413.

61. Espíndola, A.; Pellissier, L.; Alvarez, N. Variation in the proportion of flower visitors of Arum maculatum along its distributional range in relation with community-based climatic niche analyses. Oikos 2011, 120, 728-734. [CrossRef]

62. De Manincor, N.; Hautekeete, N.; Piquot, Y.; Schatz, B.; Vanappelghem, C.; Massol, F. Does phenology explain plant-pollinator interactions at different latitudes? An assessment of its explanatory power in plant-hoverfly networks in French calcareous grasslands. Peer Community Ecol. 2019, 1-55. [CrossRef]

63. Fantinato, E.; Del Vecchio, S.; Buffa, G. The co-occurrence of different grassland communities increases the stability of pollination networks. Flora 2019, 255, 11-17. [CrossRef]

64. Fossel, A.M. Les globulariacees visitees par les abeilles. Ann. L'abeille 1967, 10, 17-27. [CrossRef]

65. Outomuro, D.; Johansson, F. A potential pitfall in studies of biological shape: Does size matter? J. Anim. Ecol. 2017, 86, 1447-1457. [CrossRef]

66. Viscosi, V. Geometric morphometrics and leaf phenotypic plasticity: Assessing fluctuating asymmetry and allometry in European white oaks (Quercus). Bot. J. Linn. Soc. 2015, 179, 335-348. [CrossRef]

67. Klingenberg, C.P. Size, shape, and form: Concepts of allometry in geometric morphometrics. Dev. Genes Evol. 2016, 226, 113-137. [CrossRef]

68. Li, Z.; Yu, D. Factors affecting leaf morphology: A case study of Ranunculus natans C. A. Mey. (Ranunculaceae) in the arid zone of northwest China. Ecol. Res. 2009, 24, 1323-1333. [CrossRef]

69. Zhao, L.L.; Zhang, Y.; Wang, P.C.; Luo, T.Q.; Zhang, W.; Chen, J. Morphological and genetic variations of Sophora davidii populations originating from different altitudes in the mountains of southwestern China. Flora Morphol. Distrib. Funct. Ecol. Plants 2016, 224, 1-6. [CrossRef]

70. Tutin, T.G. Globulariaceae. In Flora Europaea; Tutin, T., Heywood, V., Burges, N., Moore, D., Valentine, D., Walters, S., Webb, D., Eds.; Cambridge University Press: Cambridge, UK, 1972; Volume 3, pp. 282-283. 
71. Friščić, M. Botanical Characteristics, Phytochemical Profile and Biological Effects of Globularia L. Species. Ph.D. Thesis, University of Zagreb, Zagreb, Croatia, 2017.

72. Crkvenčić, M.; Dudaš, S.; Jerković, I.; Marijanović, Z.; Poljuha, D.; Hazler Pilepić, K. Essential Oil Composition of Three Globularia Species. Chem. Biodivers. 2016, 13, 219-223. [CrossRef] [PubMed]

73. Friščić, M.; Bucar, F.; Hazler Pilepić, K. LC-PDA-ESI-MS ${ }^{\mathrm{n}}$ analysis of phenolic and iridoid compounds from Globularia spp. J. Mass Spectrom. 2016, 51, 1211-1236. [CrossRef] [PubMed]

74. Siljak-Yakovlev, S.; Peruzzi, L. Cytogenetic characterization of endemics: Past and future. Plant Biosyst. 2012, 146, 694-702.

75. Médail, F.; Diadema, K. Glacial refugia influence plant diversity patterns in the Mediterranean Basin. J. Biogeogr. 2009, 36, 1333-1345. [CrossRef]

76. De Castro, O.; Innangi, M.; Di Maio, A.; Menale, B.; Bacchetta, G.; Pires, M.; Noble, V.; Gestri, G.; Conti, F.; Peruzzi, L. Disentangling phylogenetic relationships in a hotspot of diversity: The butterworts (Pinguicula L., Lentibulariaceae) endemic to Italy. PLoS ONE 2016, 11, e0167610. [CrossRef]

77. Bellino, A.; Bellino, L.; Baldantoni, D.; Saracino, A. Evolution, ecology and systematics of Soldanella (Primulaceae) in the southern Apennines (Italy). BMC Evol. Biol. 2015, 15, 158. [CrossRef]

78. Peruzzi, L.; Innangi, M.; Tatino, F.; Santangelo, A. Fritillaria messanensis subsp. gracilis (Liliaceae), a new record for the Italian flora (S Italy). Phytologia 2017, 307, 167-170.

79. Cordell, S.; Goldstein, G.; Mueller-Dombois, D.; Webb, D.; Vitousek, P.M. Physiological and morphological variation in Metrosideros polymorpha, a dominant Hawaiian tree species, along an altitudinal gradient: The role of phenotypic plasticity. Oecologia 1998, 113, 188-196. [CrossRef]

80. Rohlf, F.J. The tps series of software. Hystrix 2015, 26, 1-4.

81. Cornelissen, J.H.C.; Lavorel, S.; Garnier, E.; Díaz, S.; Buchmann, N.; Gurvich, D.E.; Reich, P.B.; Ter Steege, H.; Morgan, H.D.; Van Der Heijden, M.G.A.; et al. A handbook of protocols for standardised and easy measurement of plant functional traits worldwide. Aust. J. Bot. 2003, 51, 335-380. [CrossRef]

82. Viscosi, V.; Cardini, A. Leaf morphology, taxonomy and geometric morphometrics: A simplified protocol for beginners. PLoS ONE 2011, 6, e25630. [CrossRef] [PubMed]

83. Viscosi, V.; Lepais, O.; Gerber, S.; Fortini, P. Leaf morphological analyses in four European oak species (Quercus) and their hybrids: A comparison of traditional and geometric morphometric methods. Plant Biosyst. 2009, 143, 564-574. [CrossRef]

84. Shipunov, A.B.; Bateman, R.M. Geometric morphometrics as a tool for understanding Dactylorhiza (Orchidaceae) diversity in European Russia. Biol. J. Linn. Soc. 2005, 85, 1-12. [CrossRef]

85. Van der Niet, T.; Zollikofer, C.P.E.; Ponce De León, M.S.; Johnson, S.D.; Linder, H.P. Three-dimensional geometric morphometrics for studying floral shape variation. Trends Plant Sci. 2010, 15, 423-426. [CrossRef] [PubMed]

86. Innangi, M.; Izzo, A. Pinguicula lavalvae (Lentibulariaceae), a new endemic butterwort from southern Italy diagnosed with the aid of geometric morphometrics. Plant Biosyst. 2015, 149, 990-999. [CrossRef]

87. Astuti, G.; Peruzzi, L. Are shoots of diagnostic value in Central European bladderworts (Utricularia L., Lentibulariaceae)? Plant Biosyst. 2018, 152, 1214-1226. [CrossRef]

88. Püschel, T.A.; Espejo, J.; Sanzana, M.J.; Benítez, H.A. Analysing the floral elements of the lost tree of Easter Island: A morphometric comparison between the remaining ex-situ lines of the endemic extinct species Sophora toromiro. PLoS ONE 2014, 9, e115548. [CrossRef]

89. Chuanromanee, T.S.; Cohen, J.I.; Ryan, G.L. Morphological Analysis of Size and Shape (MASS): An integrative software program for morphometric analyses of leaves. Appl. Plant Sci. 2019, 7, 1-9. [CrossRef]

90. Bardua, C.; Felice, R.N.; Watanabe, A.; Fabre, A.-C.; Goswami, A. A Practical Guide to Sliding and Surface Semilandmarks in Morphometric Analyses. Integr. Org. Biol. 2019, 1, obz016. [CrossRef]

91. Klingenberg, C.P. MorphoJ: An integrated software package for geometric morphometrics. Mol. Ecol. Resour. 2011, 11, 353-357. [CrossRef] [PubMed]

92. Innangi, M.; Balestrieri, R.; Danise, T.; d'Alessandro, F.; Fioretto, A. From soil to bird community: A Partial Least Squares approach to investigate a natural wooded area surrounded by urban patchwork (Astroni crater, southern Italy). Ecol. Modell. 2019, 394, 1-10. [CrossRef]

93. Gómez, R.; Asencio, A.D.; Picón, J.M.; Del Campo, R.; Arce, M.I.; del Mar Sánchez-Montoya, M.; Suárez, M.L.; Vidal-Abarca, M.R. The effect of water salinity on wood breakdown in semiarid Mediterranean streams. Sci. Total Environ. 2016, 541, 491-501. [CrossRef] 
94. Jinggut, T.; Yule, C.M. Leaf-litter breakdown in streams of East Malaysia (Borneo) along an altitudinal gradient: Initial nitrogen content of litter limits shredder feeding. Freshw. Sci. 2015, 34, 691-701. [CrossRef]

95. Lin, M.; Chevalier, M.; Lek, S.; Zhang, L.; Gozlan, R.E.; Liu, J.; Zhang, T.; Ye, S.; Li, W.; Li, Z. Eutrophication as a driver of $r$-selection traits in a freshwater fish. J. Fish Biol. 2014, 85, 343-354. [CrossRef] [PubMed]

96. Pellissier, L.; Pottier, J.; Vittoz, P.; Dubuis, A.; Guisan, A. Spatial pattern of floral morphology: Possible insight into the effects of pollinators on plant distributions. Oikos 2010, 119, 1805-1813. [CrossRef]

97. Cardini, A.; Alexandre, J.; Diniz, F.; Polly, P.D. Biogeographic Analysis Using Geometric Morphometrics: Clines in Skull Size and Shape in a Widespread African Arboreal Monkey. In Morphometrics for Nonmorphometricians; Elewa, A.M.T., Ed.; Lecture Notes in Earth Sciences; Springer: Berlin/Heidelberg, Germany, 2010; Volume 124, pp. 191-217, ISBN 978-3-540-95852-9.

98. Botes, A.; McGeoch, M.A.; Robertson, H.G.; van Niekerk, A.; Davids, H.P.; Chown, S.L. Ants, altitude and change in the northern Cape Floristic Region. J. Biogeogr. 2006, 33, 71-90. [CrossRef]

99. Danise, T.; Fioretto, A.; Innangi, M. Spectrophotometric methods for lignin and cellulose in forest soils as predictors for humic substances. Eur. J. Soil Sci. 2018, 69, 856-867. [CrossRef]

100. Zhang, L.; Wylie, B.K.; Ji, L.; Gilmanov, T.G.; Tieszen, L.L. Climate-driven interannual variability in net ecosystem exchange in the Northern Great Plains grasslands. Rangel. Ecol. Manag. 2010, 63, 40-50. [CrossRef]

101. Zuur, A.F.; Ieno, E.N.; Elphick, C.S. A protocol for data exploration to avoid common statistical problems. Methods Ecol. Evol. 2010, 1, 3-14. [CrossRef]

102. Gustafson, W.I.; Yu, S. Generalized approach for using unbiased symmetric metrics with negative values: Normalized mean bias factor and normalized mean absolute error factor. Atmos. Sci. Lett. 2012, 13, $262-267$. [CrossRef]

103. King, T.S.; Chinchilli, V.M. A generalized concordance correlation coefficient for continuous and categorical data. Stat. Med. 2001, 20, 2131-2147. [CrossRef] [PubMed]

104. Green, P.J.; Silverman, B.W. Chapman \& Hall/CRC Monographs on Statistics \& Applied Probability. In Nonparametric Regression and Generalized Linear Models: A Roughness Penalty Approach; CRC Press: Boca Raton, FL, USA, 1993; ISBN 9780412300400.

105. R Core Team. Team R: A Language and Environment for Statistical Computing; R Foundation for Statistical Computing: Vienna, Austria. Available online: https://www.r-project.org/ (accessed on 12 January 2019). 